Article

\title{
A Causal Network-Based Risk Matrix Model Applicable to Shield TBM Tunneling Projects
}

\author{
Heeyoung Chung ${ }^{1}{ }^{\mathbb{D}}$, Jeongjun Park ${ }^{2}$, Byung-Kyu Kim ${ }^{2}$, Kibeom Kwon ${ }^{3}$, In-Mo Lee ${ }^{3}$ and Hangseok Choi ${ }^{3, * \mathbb{C}}$ \\ 1 Technology Research Team, Incheon International Airport Corporation, Incheon 22382, Korea; \\ heeyoung.chung@airport.kr \\ 2 Advanced Infrastructure Research Team, Korea Railroad Research Institute, Uiwang 16105, Korea; \\ jjpark@krri.re.kr (J.P.); bkkim86@krri.re.kr (B.-K.K.) \\ 3 School of Civil, Environmental and Architectural Engineering, Korea University, Seoul 02841, Korea; \\ kibb5@korea.ac.kr (K.K.); inmolee@korea.ac.kr (I.-M.L.) \\ * Correspondence: hchoi2@korea.ac.kr; Tel.: +82-2-3290-3326
}

Citation: Chung, H.; Park, J.; Kim, B.-K.; Kwon, K.; Lee, I.-M.; Choi, H. A Causal Network-Based Risk Matrix Model Applicable to Shield TBM Tunneling Projects. Sustainability 2021, 13, 4846. https://doi.org/10.3390/ su13094846

Academic Editor: Sotiris Argyroudis

Received: 22 February 2021

Accepted: 9 April 2021

Published: 26 April 2021

Publisher's Note: MDPI stays neutral with regard to jurisdictional claims in published maps and institutional affiliations.

Copyright: (C) 2021 by the authors Licensee MDPI, Basel, Switzerland This article is an open access article distributed under the terms and conditions of the Creative Commons Attribution (CC BY) license (https:// creativecommons.org/licenses/by/ $4.0 /)$.
Abstract: The present study compares and analyzes three risk analysis models that are applicable to shield tunnel boring machine (TBM) tunneling, and thus proposes an improved risk matrix model based on the causal networks applicable to sustainable tunnel projects. The advantages and disadvantages of three risk analysis models are compared, and causal networks are structured by analyzing the causal relationship between risk factors and risk events. Based on the comparison and analysis results, the causal network-based risk matrix model (CN-Matrix model), which complements the disadvantages and exploits the advantages of the three existing models, is proposed in this paper. Furthermore, this study suggests a means of modifying the weighting scores in the estimation of the risk score, which permits the $\mathrm{CN}$-Matrix model to determine the risk level more reasonably. Thus, the improved CN-Matrix model is more reliable and robust compared to the three existing models.

Keywords: shield tunnel boring machine (TBM); risk analysis; risk matrix; causal network; CN-Matrix model; fault tree analysis (FTA); analytic hierarchy process (AHP); Bayesian network; shield TBM risk analysis model (STRAM)

\section{Introduction}

Recently, the demands for new underground infrastructures have increased [1]. Risk management has increasingly become important for a number of projects in various industries including the construction of infrastructures [2-4]. In the case of tunnel constructions, as the geotechnical investigation at the design stage covers a large area, uncertainty always exists in the investigation results. Therefore, unexpected geological conditions can be encountered during tunneling. Unless proper countermeasures are adopted for risky ground conditions, construction cost and time may increase significantly, and lives may be lost because of tunnel collapses. Therefore, a systematic method of risk analysis, applicable at both the design and construction stages, is indispensable for ensuring safety and economic sustainability in tunnel projects.

The Land Transport Authority $(2012,2018)$ of Singapore specifies the standards and regulations for risk management that contractors are required to apply from the bidding stage of tunnel projects; the contractors are also compelled to manage risks at all stages of projects [5,6]. WSP | Parsons Brinckerhoff (2016) developed a risk analysis tool through the National Cooperative Highway Research Program (NCHRP) and carried out risk analyses in many construction projects [7]. However, this tool only explains the requirements and suggestions for general risk analysis and management, so it does not systematically provide risk analysis methods that are applicable to actual shield tunnel boring machine (TBM) tunneling projects. 
In South Korea, the Design for Safety (DFS) has been legalized in the safety management performance guideline of the Ministry of Land, Infrastructure, and Transport (2017), which requires that a risk analysis should be performed for every construction project [8]. Furthermore, the Korea Expressway Corporation Research Institute (2017) developed an internal guide for a tunnel risk management system, which was applied to tunnel projects in charge of the Korea Expressway Corporation [9].

The present study proposes an improved matrix model, which is the causal networkbased risk matrix model (CN-Matrix model), applicable to actual shield TBM tunneling projects. To verify the capacity of the proposed $\mathrm{CN}-$ Matrix model, the existing three risk analysis models that are applicable to actual shield TBM tunneling projects were analyzed, and their advantages and disadvantages were compared. In addition, the potential risk events that may occur during shield TBM tunnel construction, and their causal risk factors were identified. Then, causal networks were structured by analyzing the causal relationship between risk factors and risk events. Furthermore, this study suggests a way to modify the weighting scores for two categories of the risk matrix, so that the CN-Matrix model can determine the risk level with a high degree of reliability.

\section{Tunnel Risk Analysis Models}

Among various risk analysis models applied to a variety of fields, five models are widely adopted in tunneling projects. These risk analysis models use various analysis tools, and some of them are specialized for tunnel projects. Each of these risk analysis models is briefly described in this section.

\subsection{Decision Aids for Tunneling}

The decision aids for tunneling (DAT), developed by Einstein et al. (1999), enables the engineers to perform simulations considering the uncertainties in the geology and construction process for a given tunneling project and to simultaneously present the probability distributions of the tunnel construction cost and time [10]. To consider uncertain geological characteristics, various ground profiles are represented as probability distributions. Based on them, the probability distributions of the construction cost and time of the entire project can be obtained. Min et al. (2005) applied the DAT technique to predict and update the total construction cost and time of a road tunnel project [11].

\subsection{Risk Evaluation Based on Event Tree Analysis}

The event tree analysis (ETA) is an inductive system analysis technique that uses the initiating event (a defect in the system, process, construction, etc.) of an accident as the starting point and schematically expresses the expected consequences of the accident from the initiating event. The ETA is one of the system models that represent the system safety based on the safety of each event. An event tree is composed of the initiating event (the cause of the accident), potential sub-risk events, and final consequences of the event. The potential sub-risk events are mutually exclusive, and the consequences are dependent on the sub-risk events that occur due to the initiating event. Therefore, the probability of occurrence of a specific path can be calculated by multiplying the probabilities of all sub-risk events that exist on this path. Hong et al. (2009) utilized the ETA technique to carry out a risk analysis for an under-river shield TBM tunnel project crossing the Han River in part of Seoul subway construction [12].

\subsection{Risk Analysis Based on Matrix Model}

\subsubsection{Risk Matrix Model}

The risk matrix model, which is the most popular model in construction projects, has been proposed in various forms as a basic tool for qualitative risk analysis and assessment, as shown in Figure 1. The risk matrix is composed of two categories: the frequency of an event and its consequence. The risk level can then be determined by combining these two categories. The risk is usually divided into three to five levels; the matrix described in 
Figure 1 divides the risk into four levels as follows: Negligible, Acceptable, Unwanted, and Unacceptable. Figure 1 shows the risk matrix proposed by the International Tunnelling and Underground Space Association (ITA), named the ITA-Matrix model, and the classifications of frequency and consequence (or impact) are presented in Tables 1 and 2, respectively.

\begin{tabular}{|c|c|c|c|c|c|}
\hline \multirow{2}{*}{ Frequency } & \multicolumn{5}{|c|}{ Consequence } \\
\cline { 2 - 6 } & Insignificant & Considerable & Serious & Severe & Disastrous \\
\hline \multirow{2}{*}{ Very unlikely } & $\begin{array}{c}\text { Negligible } \\
\text { (I) }\end{array}$ & $\begin{array}{c}\text { Negligible } \\
\text { (I) }\end{array}$ & $\begin{array}{c}\text { Acceptable } \\
\text { (II) }\end{array}$ & $\begin{array}{c}\text { Acceptable } \\
\text { (II) }\end{array}$ & $\begin{array}{c}\text { Unwanted } \\
\text { (III) }\end{array}$ \\
\hline Unlikely & $\begin{array}{c}\text { Negligible } \\
\text { (I) }\end{array}$ & $\begin{array}{c}\text { Acceptable } \\
\text { (II) }\end{array}$ & $\begin{array}{c}\text { Acceptable } \\
\text { (II) }\end{array}$ & $\begin{array}{c}\text { Unwanted } \\
\text { (III) }\end{array}$ & $\begin{array}{c}\text { Unwanted } \\
\text { (III) }\end{array}$ \\
\hline Occasional & $\begin{array}{c}\text { Acceptable } \\
\text { (II) }\end{array}$ & $\begin{array}{c}\text { Acceptable } \\
\text { (II) }\end{array}$ & $\begin{array}{c}\text { Unwanted } \\
\text { (III) }\end{array}$ & $\begin{array}{c}\text { Unwanted } \\
\text { (III) }\end{array}$ & $\begin{array}{c}\text { Unacceptable } \\
\text { (IV) }\end{array}$ \\
\hline Likely & $\begin{array}{c}\text { Acceptable } \\
\text { (II) }\end{array}$ & $\begin{array}{c}\text { Unwanted } \\
\text { (III) }\end{array}$ & $\begin{array}{c}\text { Unwanted } \\
\text { (III) }\end{array}$ & $\begin{array}{c}\text { Unacceptable } \\
\text { (IV) }\end{array}$ & $\begin{array}{c}\text { Unacceptable } \\
\text { (IV) }\end{array}$ \\
\hline Very likely & $\begin{array}{c}\text { Unwanted } \\
\text { (III) }\end{array}$ & $\begin{array}{c}\text { Unwanted } \\
\text { (III) }\end{array}$ & $\begin{array}{c}\text { Unacceptable } \\
\text { (IV) }\end{array}$ & $\begin{array}{c}\text { Unacceptable } \\
\text { (IV) }\end{array}$ & $\begin{array}{c}\text { Unacceptable } \\
\text { (IV) }\end{array}$ \\
\hline
\end{tabular}

Figure 1. Risk Matrix Proposed by International Tunnelling and Underground Space Association (ITA) [13].

Table 1. Frequency Classification [13].

\begin{tabular}{ccc}
\hline Class & Interval $^{\mathbf{1}}$ & Central Value $^{\mathbf{1}}$ \\
\hline Very likely & $>0.3$ & 1 \\
\hline Likely & 0.03 to 0.3 & 0.1 \\
\hline Occasional & 0.003 to 0.03 & 0.01 \\
\hline Unlikely & 0.0003 to 0.003 & 0.001 \\
\hline Very unlikely & $<0.0003$ & 0.0001 \\
\hline
\end{tabular}

${ }^{1}$ Unit: potential number of events per year (during the whole construction period).

Table 2. Consequence Classification [13].

\begin{tabular}{|c|c|c|c|c|c|c|}
\hline Class & $\begin{array}{l}\text { Injury to Workers } \\
\text { and Emergency } \\
\text { Crew [No. of } \\
\text { Fatalities/Injuries] }{ }^{1}\end{array}$ & $\begin{array}{c}\text { Injury to Third } \\
\text { Parties [No. of } \\
\text { Fatalities/Injuries] }{ }^{1}\end{array}$ & $\begin{array}{l}\text { Damage or } \\
\text { Economic Loss to } \\
\text { the Third Party } \\
\text { [Loss in } \\
\text { Million Euro] }\end{array}$ & $\begin{array}{l}\text { Harm to the } \\
\text { Environment } \\
\text { [Guideline for } \\
\text { Proportions } \\
\text { of Damage] }\end{array}$ & $\begin{array}{c}\text { Delay [Months } \\
\text { per Hazard] }\end{array}$ & $\begin{array}{l}\text { Economic } \\
\text { Loss to the } \\
\text { Owner } \\
\text { [Loss in } \\
\text { Million Euro] }\end{array}$ \\
\hline Disastrous & $\mathrm{F}>10$ & $\begin{array}{r}\mathrm{F}>1 \\
\mathrm{SI}>10\end{array}$ & $>3$ & $\begin{array}{c}\text { Permanent } \\
\text { severe damage }\end{array}$ & $>10$ or $>24$ & $>30$ \\
\hline Severe & $\begin{array}{c}1<\mathrm{F} \leq 10 \\
\mathrm{SI}>10\end{array}$ & $1<\frac{1 F}{S I} \leq 10$ & $0.3-3$ & $\begin{array}{c}\text { Permanent } \\
\text { minor damage }\end{array}$ & $1-10$ or $6-24$ & $3-30$ \\
\hline Serious & $\begin{array}{c}1 \mathrm{~F} \\
1<\mathrm{SI} \leq 10\end{array}$ & $\begin{array}{c}1 \mathrm{SI} \\
1<\mathrm{MI} \leq 10\end{array}$ & $0.03-0.3$ & Long-term effects & $0.1-1$ or $2-6$ & $0.3-3$ \\
\hline Considerable & $\begin{array}{c}1 \mathrm{SI} \\
1<\mathrm{MI} \leq 10\end{array}$ & $1 \mathrm{MI}$ & $0.003-0.03$ & $\begin{array}{c}\text { Temporary } \\
\text { severe damage }\end{array}$ & $0.01-0.1$ or $1 / 2-2$ & $0.03-0.3$ \\
\hline Insignificant & $1 \mathrm{MI}$ & - & $<0.003$ & $\begin{array}{c}\text { Temporary } \\
\text { minor damage }\end{array}$ & $<0.01$ or $<1 / 2$ & $<0.03$ \\
\hline
\end{tabular}

${ }^{1} \mathrm{~F}$, fatality; SI, serious injury; and MI, minor injury.

\subsubsection{Risk Matrix Model Using Fault Tree Analysis and Analytic Hierarchy Process}

Hyun et al. (2015) proposed a risk matrix model using probability and impact as the frequency and consequence categories of risk events, respectively. In addition, to obtain a quantitative decision of these categories, they used the fault tree analysis (FTA) and the analytic hierarchy process (AHP) [14]. The risk matrix using the FTA and AHP, named the FTA-AHP Matrix model, is shown in Figure 2. 

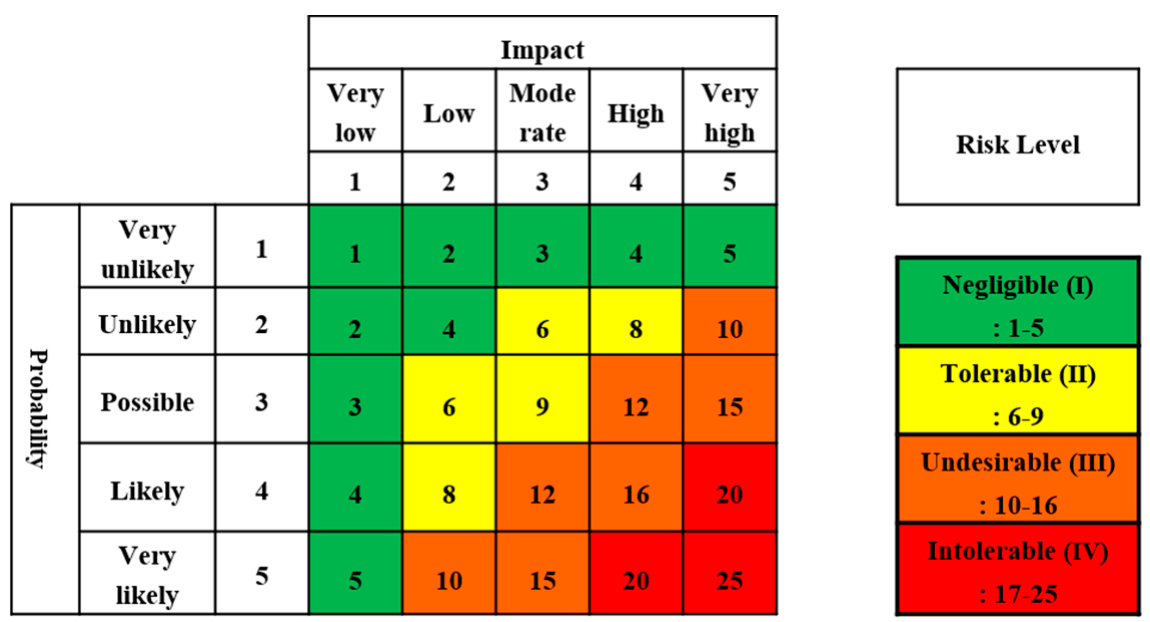

Figure 2. Risk Matrix using fault tree analysis (FTA) and analytic hierarchy process (AHP) [14].

The FTA is a method for analyzing the causes of risks in a deductive method. A specific accident or a risk associated with a primary system, recognized from a qualitative assessment, is placed as the top event in the tree for deductive reasoning. It can clarify the theoretical relationship between top events and risk factors and quantitatively predict the occurrence of the top event based on the probability of each risk factor. Hence, the probability category can be quantitatively determined using the FTA. Liu et al. (2014) adopted the FTA-based method for the risk decision-making process in emergency response [15]. Zhou et al. (2019) used the FTA for evaluating the probabilities of potential severe results to select an optimal rescue plan [16].

The AHP is a decision-making process developed by Saaty (1980) [17]. The process can systematically prioritize various alternatives that can be selected by a decision-maker along with the effective application of the multi-criteria decision-making process, which involves attributes and measurement criteria of decision-making factors. Therefore, the AHP can be used to quantitatively determine the impact of risks. In other words, the impact of each risk can be determined by assigning a weighting factor to the risk. Hyun et al. (2015) applied the FTA-AHP Matrix model to a Seoul subway tunneling job site, in which a slurry shield TBM was adopted.

\subsection{Risk Analysis Model Using Bayesian Network}

The shield TBM risk analysis model using the Bayesian network (STRAM-BN) was proposed by Chung et al. (2019) [18]. This model is based on the causal relationships between potential risk events and the risk factors causing the events; it can identify major risk events that may occur during tunneling construction and assess the risk degrees of these potential risk events. To assess risk events quantitatively by reflecting the dependence on the causal relationships between risk factors and risk events, the STRAM-BN uses the Bayesian network, which presents the occurrences of causes and events as conditional probabilities. The schematic of the proposed STRAM-BN is shown in Figure 3. The STRAM$\mathrm{BN}$ evaluates the risk degree by considering the nodes of the STRAM-BN such as the types of TBM, geological risk factors, risk events, countermeasures, direct cost, and indirect cost. Furthermore, the risk response phase of the STRAM-BN that corresponds to the risk level in the risk matrix model is presented in Table 3, which was determined based on the case histories collected from around the world. Chung et al. (2019) quantitatively assessed the degree of risk events by applying the STRAM-BN for a subsea tunnel project adopting an EPB shield TBM. 


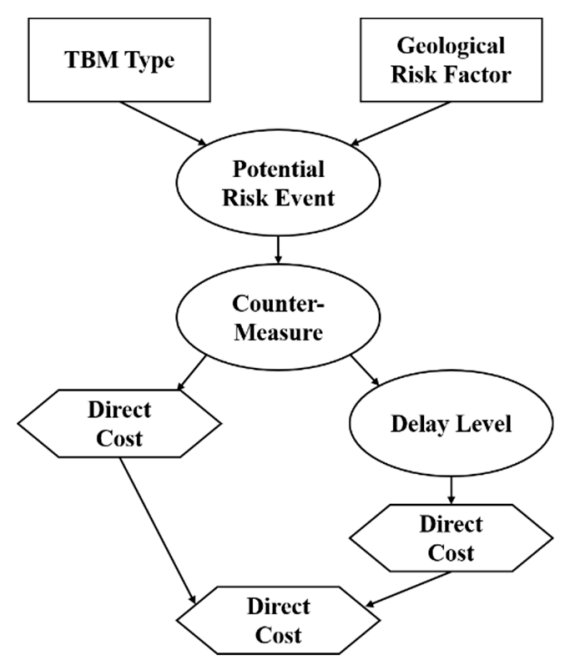

Figure 3. Schematic of the shield TBM risk analysis model using the Bayesian network (STRAM-BN) [18].

Table 3. Risk Response Phase [18].

\begin{tabular}{ccc}
\hline Response Phase & Degree of Risk ${ }^{\mathbf{1}}$ & Description \\
\hline I & $0-10$ & Excavation without mitigation measure owing to a low degree of risk \\
\hline II & $10-30$ & Excavation with the intention to prepare for the risk \\
\hline III & $30-80$ & Excavation with mitigation measure owing to a high degree of risk \\
\hline IV & $>80$ & Unconditionally applying mitigation measure owing to a very high degree of risk \\
\hline
\end{tabular}

\section{Development of Causal Network-based Risk Matrix Model}

Among the above risk analysis models, the three risk analysis models (ITA-Matrix model, FTA-AHP Matrix model, and STRAM-BN) are compared to derive an improved risk matrix model based on the causal networks in this study.

The ITA-Matrix model in Figure 1 is a qualitative risk analysis model that represents the frequency and consequence categories of the matrix as qualitative classes and determines the risk degree by combining the frequency and consequence classes. Herein, the classification criteria of frequency and consequence rely on mainly the experiences of tunneling experts. Furthermore, the ITA-Matrix model is a general guideline for tunneling risk management but does not realize the detailed identification of risk factors and risk events that are relevant to shield TBM tunnels. In addition, this model cannot consider the causal relationship between the risk factors and risk events.

The FTA-AHP Matrix model shown in Figure 2 has the advantages of representing the probability and impact using quantitative classes ranging from 1 to 5 points along with the FTA and AHP, which can calculate the risk degree by multiplying the probability and impact scores, as expressed in Equation (1).

$$
\text { Risk degree }=\text { Probability score } \times \text { Impact score, }
$$

Furthermore, it can systematically analyze potential risk events during shield TBM tunneling by examining the causal relationships between risk factors and risk events for shield TBM tunnels.

The STRAM-BN is a quantitative risk analysis model specialized for shield TBM tunnels and analyzes risks based on the causal relationship between a potential risk event and its causal risk factor during shield TBM tunnel excavation. This is similar to the manner in the FTA-AHP Matrix model. The STRAM-BN has the advantages of reflecting causal relationships using the conditional probabilities of potential risk events from the 
corresponding geological risk factor and TBM type, and further reflecting job site conditions, which considers the cost of the appropriate countermeasure.

The comparison of these three tunnel risk analysis models is summarized in Tables 4-7 with respect to the following key items: frequency (probability), consequence (impact), risk degree, and risk level (risk response phase), respectively.

Table 4. Frequency (Probability) comparison of ITA-Matrix Model, FTA-AHP Matrix Model, and STRAM-BN.

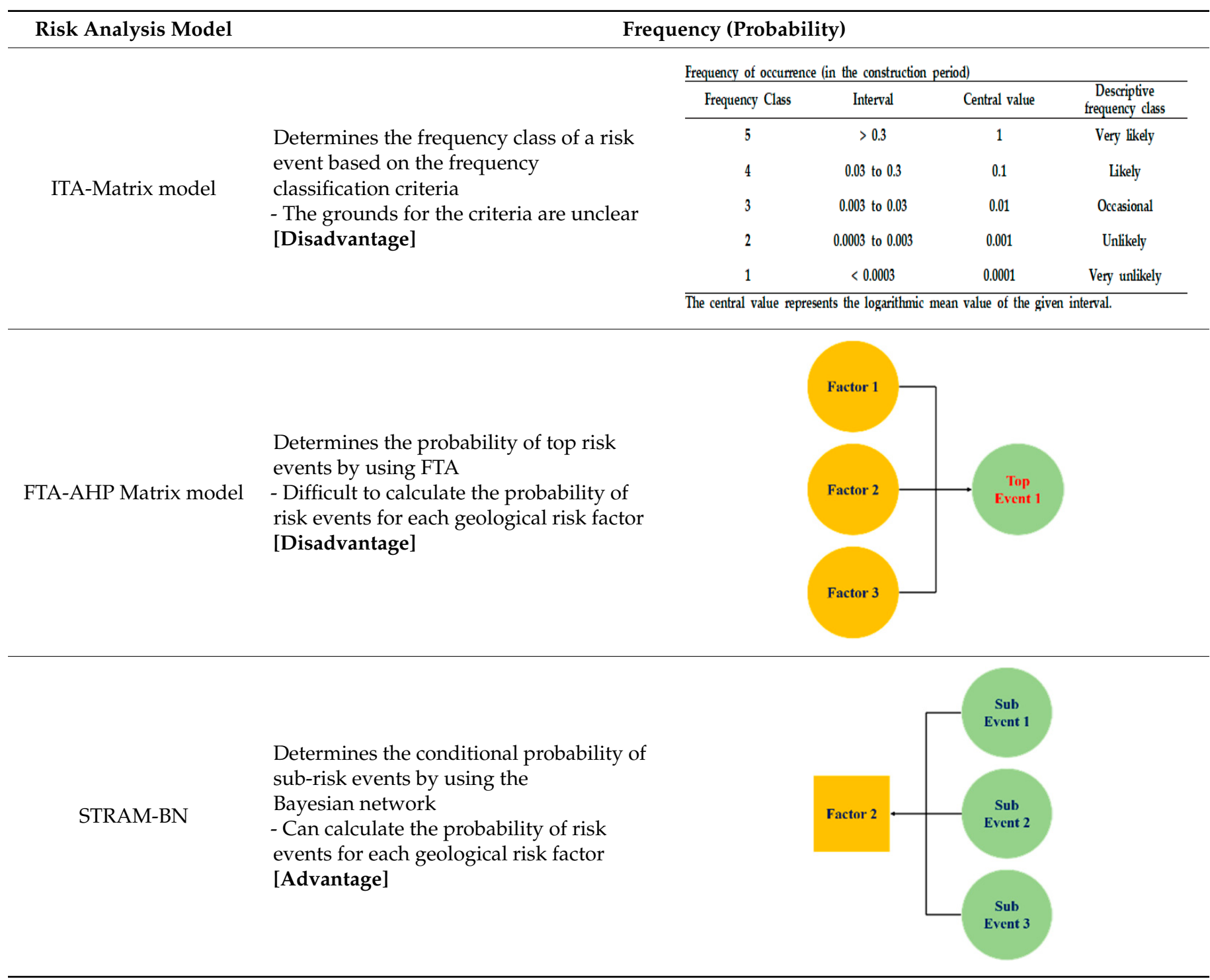

Table 5. Consequence (Impact) comparison of ITA-Matrix Model, FTA-AHP Matrix Model, and STRAM-BN.

\begin{tabular}{cl}
\hline Risk Analysis Model & \multicolumn{1}{c}{ Consequence (Impact) } \\
\hline ITA-Matrix model & $\begin{array}{l}\text { Determines the consequence class based on the classification criteria of six consequence analysis items } \\
\text { - The grounds for the criteria are unclear [Disadvantage] }\end{array}$ \\
\hline FTA-AHP Matrix model & Can determine the impact of top risk events using AHP even without cost estimation [Advantage] \\
\hline STRAM-BN & Cost of countermeasure of the site are required [Disadvantage] \\
\cline { 2 - 2 } & $\begin{array}{l}\text { The consequence analysis results with consequence using the detailed countermeasure cost of the site } \\
\text { further reflect site conditions [Advantage] }\end{array}$ \\
\hline
\end{tabular}


Table 6. Risk degree comparison of ITA-Matrix Model, FTA-AHP Matrix Model, and STRAM-BN.

\begin{tabular}{|c|c|}
\hline Risk Analysis Model & Risk Degree \\
\hline \multirow{4}{*}{ ITA-Matrix model } & Combination of frequency and consequence classes \\
\hline & -Relatively easy to determine [Advantage] \\
\hline & -It is based on qualitative analysis results [Disadvantage] \\
\hline & $\begin{array}{l}\text { Difficult to determine the risk degree of potential risk events resulting from each geological risk } \\
\text { factor [Disadvantage] }\end{array}$ \\
\hline \multirow{2}{*}{ FTA-AHP Matrix model } & $\begin{array}{l}\text { Probability score } \times \text { Impact score } \\
(1-5 \text { points })(1-5 \text { points }) \\
\text { - Relatively easy to determine [Advantage] } \\
\text { - Quantitative analysis results [Advantage] }\end{array}$ \\
\hline & $\begin{array}{l}\text { Difficult to determine the risk degree of potential risk events resulting from each geological risk } \\
\text { factor [Disadvantage] } \\
\text { - Difficult to reflect site ground conditions } \\
\text { - Difficult to apply to the construction stage }\end{array}$ \\
\hline \multirow{2}{*}{ STRAM-BN } & $\begin{array}{l}\text { Probability } \times \text { Countermeasure cost } \\
(1-5 \text { points })(1-5 \text { points }) \\
\text { - Relatively complex to calculate [Disadvantage] } \\
\text { - Quantitative analysis results [Advantage] }\end{array}$ \\
\hline & $\begin{array}{l}\text { Can determine the risk degree of potential risk events resulting from each geological risk factor } \\
\text { [Advantage] } \\
\text { - Can reflect the site ground conditions } \\
\text { - Applicable to the construction stage as well as to the design stage }\end{array}$ \\
\hline
\end{tabular}

Table 7. Risk level (Risk response phase) comparison of ITA-Matrix Model, FTA-AHP Matrix Model, and STRAM-BN.

\begin{tabular}{|c|c|}
\hline Risk Analysis Model & Risk Level (Risk Response Phase) \\
\hline ITA-Matrix model & $\begin{array}{ll}\text { - } & \text { I: Negligible } \\
\text { - } & \text { II: Acceptable } \\
\text { - } & \text { III: Unwanted } \\
\text { - } & \text { IV: Unacceptable }\end{array}$ \\
\hline FTA-AHP Matrix model & $\begin{array}{ll}\bullet & \text { I (Negligible): 1-5 } \\
\text { - } & \text { II (Tolerable): 6-9 } \\
\text { - } & \text { III (Undesirable): 10-16 } \\
\text { - } & \text { IV (Intolerable): 17-25 } \\
\text { [Unit: scores] }\end{array}$ \\
\hline STRAM-BN & $\begin{array}{ll}- & \text { I: } 0-10 \\
\text { - } & \text { II: } 10-30 \\
\text { - } & \text { III: } 30-80 \\
\text { - } & \text { IV: } 80-\infty \\
\text { [Unit: } \times 10^{3} \text { US dollars] }\end{array}$ \\
\hline
\end{tabular}

The concept of conditional probability is applied only in the STRAM-BN, not in the FTA-AHP Matrix model. Therefore, unlike the STRAM-BN, the FTA-AHP Matrix model has a limitation to calculate the probability of a risk event for each geological risk factor.

In the case of the STRAM-BN, the consequence and/or impact of a risk event is judged based on the cost that is needed to implement the suitable countermeasure when the event occurs. Unlike the STRAM-BN, the FTA-AHP Matrix model does not require the detailed countermeasure cost reflecting job site conditions because the impact is determined based on the relative downtimes caused by each risk event using the AHP. For this reason, the FTA-AHP Matrix model seems to be easier and more efficient.

The ITA-Matrix model qualitatively determines the risk degree by combining the five frequency classes and consequence classes. The FTA-AHP Matrix model determines 
the risk degree by Equation (1). The STRAM-BN determines the risk degree in terms of the conditional probability of risk events and the cost of countermeasures (direct and indirect costs considering the delay level) at each job site. Thus, the risk levels of the ITA-Matrix model, which is a qualitative analysis model, are represented by four levels (Negligible, Acceptable, Unwanted, Unacceptable), whereas in the case of the FTA-AHP Matrix model and the STRAM-BN, which quantitatively analyze risks, the risk degrees are represented by points of 1-25 (unit: scores) and by costs of $0-\infty$ (unit: $\times 10^{3}$ US dollars), respectively. Herein, the upper and lower limits of the risk degree in the STRAM-BN do not exist because the cost of countermeasure implementation is limitless. The risk levels (risk response phases) are divided into four steps for both the risk matrix models and the STRAM-BN; however, the direct comparison of the risk degrees according to the risk level is challenging because the unit of the risk degree is different in each case.

In this paper, a causal network-based risk matrix model, the CN-Matrix model, applicable to actual shield TBM tunnels, is proposed by modifying the existing FTA-AHP Matrix model to complement its drawbacks. Like the FTA-AHP Matrix model, the risk degree in the CN-Matrix model is also calculated by Equation (1) and using the identical risk matrix and risk levels shown in Figure 2. As for the consequence (impact) in the CN-Matrix model, the AHP is adopted the same as the FTA-AHP Matrix model for better application in practice rather than the STRAM-BN. However, unlike the FTA-AHP Matrix model that uses the relative weight (impact) of downtimes of the top risk events, the CN-Matrix model adopts the impact of the sub-risk events. Therefore, the potential sub-risk events should be selected among all the 16 sub-risk events to apply the AHP for the designated job site. It can perform risk analyses based on sub-risk events rather than top risk events by evaluating the risk degree of the sub-risk events caused by each geological risk factor with consideration of conditional probability; hence, this model can be used to perform risk analyses in both the design and construction stages. The conditional probability is adopted in the CN-Matrix model, not in the FTA-AHP Matrix model. In the FTA-AHP Matrix model, the probability of a geological risk factor has the same effect on all sub-risks. However, in the CN-Matrix model, its probability depends on the specific sub-risk event. Causal networks between the potential geological risk factors and their corresponding risk events during shield TBM tunnel excavation are structured as shown in Figure 4 . The geological risk factors and the risk events adopted in the CN-Matrix model are listed in Tables 8 and 9, respectively.

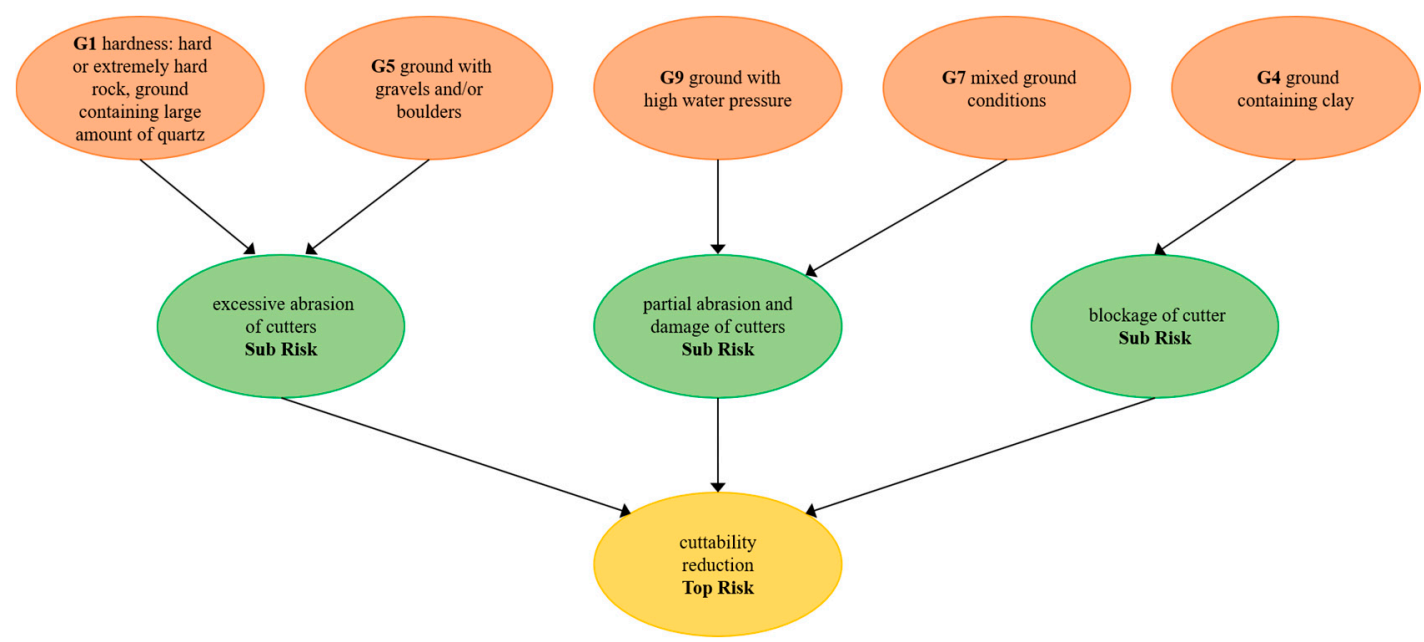

(a)

Figure 4. Cont. 


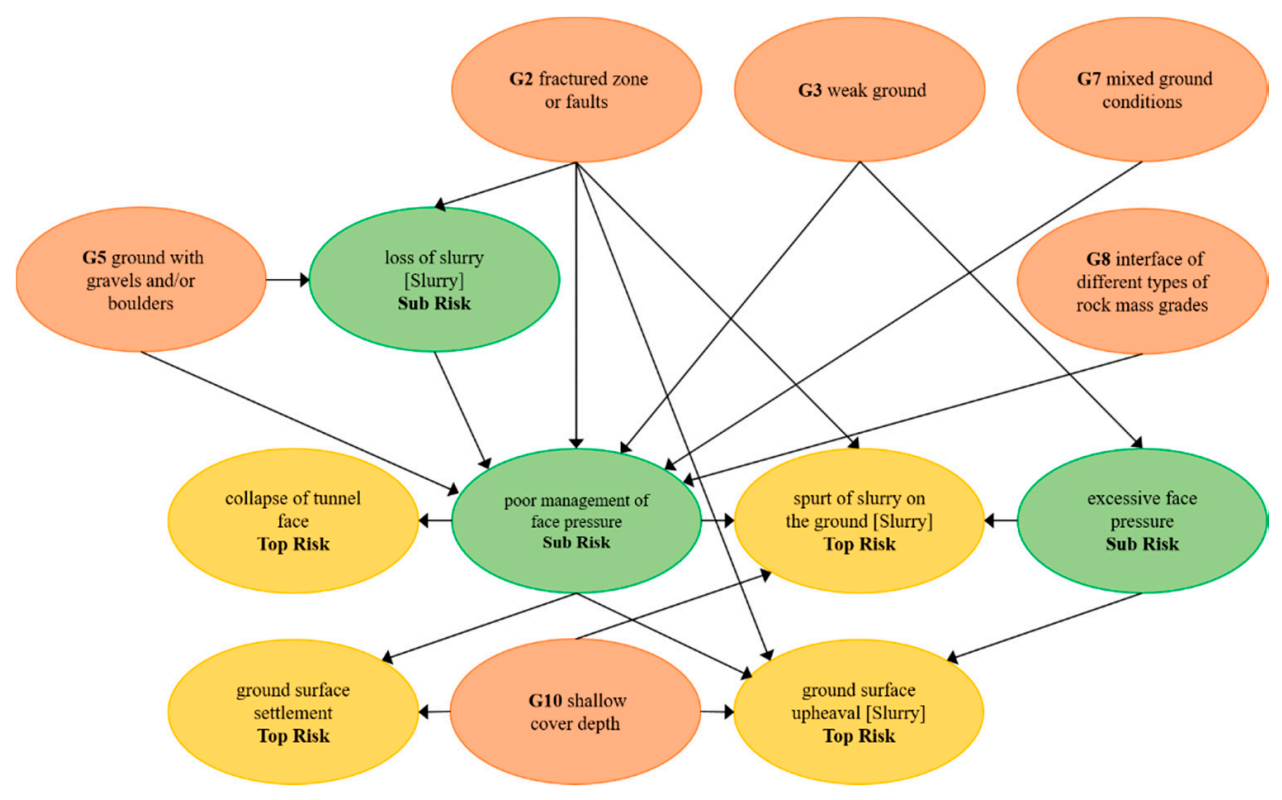

(b)

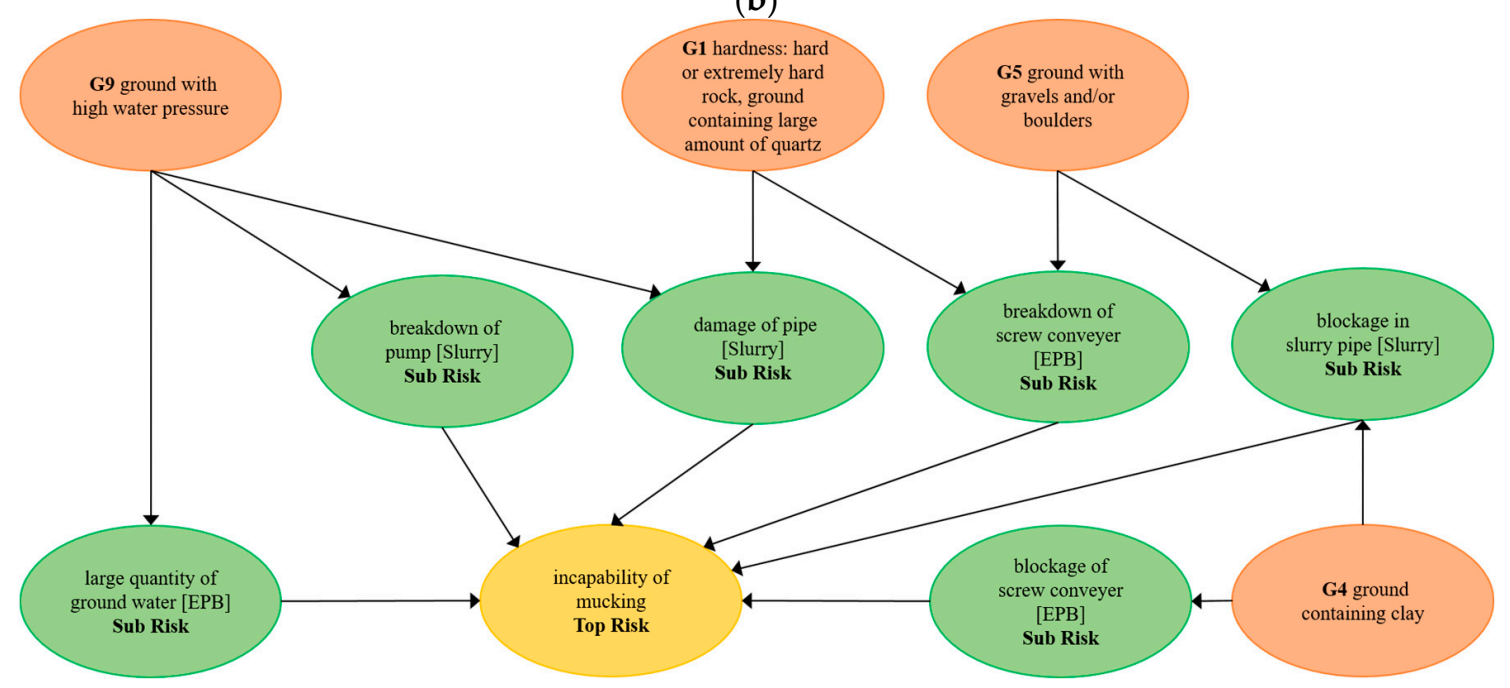

(c)

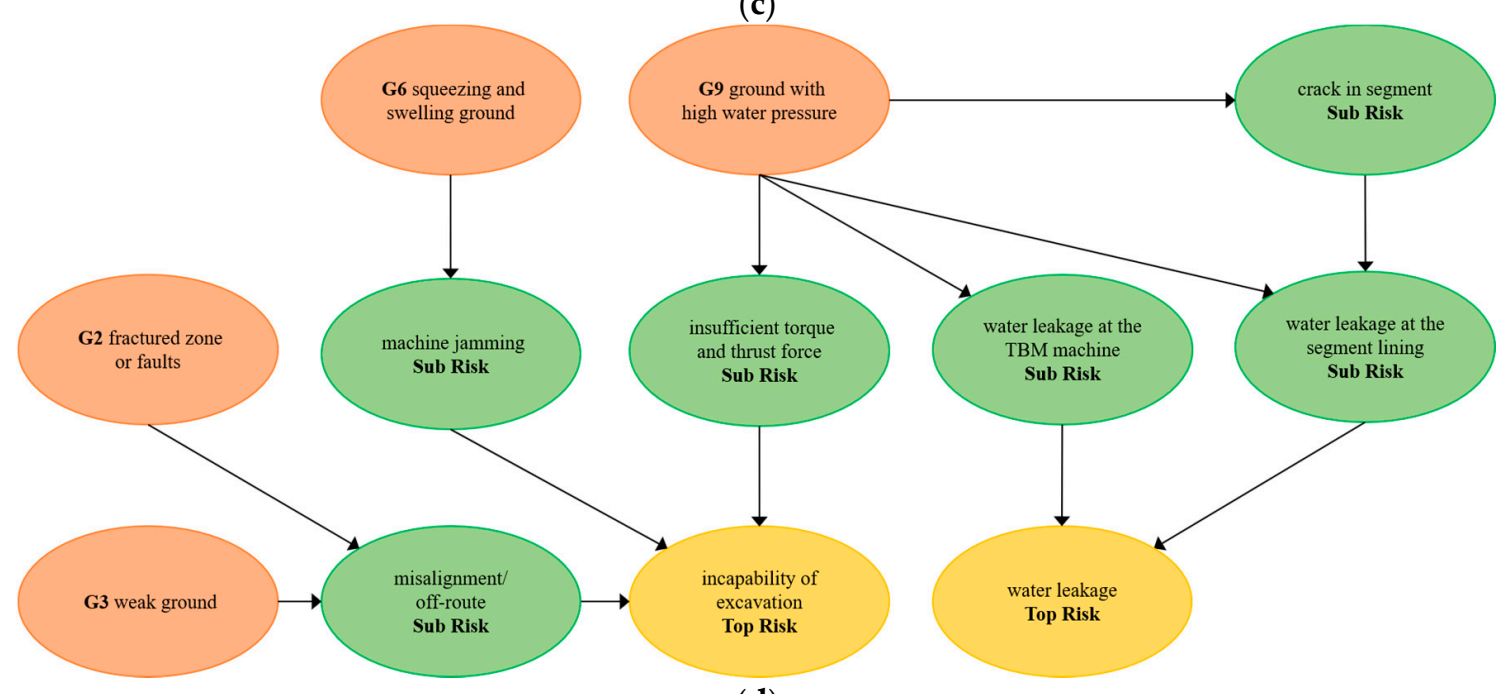

(d)

Figure 4. Causal Networks between Geological Risk Factors and Risk Events: (a) Cuttability Reduction; (b) Those Related to Applying Face Pressure; (c) Incapability of Mucking; (d) Incapability of Excavation and Water Leakage. 
Table 8. Geological Risk Factors [18].

\begin{tabular}{cc}
\hline Class & Geological Risk Factor \\
\hline G1 & Hardness: hard or extremely hard rock, ground containing a large amount of quartz \\
\hline G2 & Fractured zone or faults \\
\hline G3 & Weak ground \\
\hline G4 & Ground containing clay \\
\hline G5 & Ground with gravels and or boulders \\
\hline G6 & Mixed ground conditions \\
\hline G7 & Interface of different types of rock mass grades \\
\hline G8 & Ground with high water pressure \\
\hline G9 & Shallow cover depth \\
\hline
\end{tabular}

Table 9. Potential Risk Events during Shield TBM Construction [18].

\begin{tabular}{|c|c|c|c|}
\hline \multirow{2}{*}{ Top Risk Event } & \multirow{2}{*}{ Sub-Risk Event } & \multicolumn{2}{|c|}{ Risk Event No. } \\
\hline & & STRAM-BN/CN-Matrix & FTA-AHP Matrix \\
\hline \multirow{3}{*}{ Cuttability reduction } & Excessive abrasion of cutters & RE1-1 & \multirow{3}{*}{$\mathrm{T} 1$} \\
\hline & Partial abrasion and damage of cutters & RE1-2 & \\
\hline & Blockage of cutter & RE1-3 & \\
\hline \multicolumn{2}{|c|}{ Collapse of tunnel face } & RE2 & $\mathrm{T} 2$ \\
\hline \multicolumn{2}{|c|}{ Ground surface settlement } & RE3 & $\mathrm{T} 3$ \\
\hline \multicolumn{2}{|c|}{ Ground surface upheaval [Slurry] } & RE4 & \multirow{2}{*}{$\mathrm{T} 4$} \\
\hline \multicolumn{2}{|c|}{ Spurt of slurry on the ground [Slurry] } & RE5 & \\
\hline \multirow{3}{*}{ Incapability of mucking [EPB] } & Large quantity of groundwater & RE6-1 & \multirow{3}{*}{$\mathrm{T} 5$} \\
\hline & Breakdown of screw conveyor & RE6-2 & \\
\hline & Blockage of screw conveyor & RE6-3 & \\
\hline \multirow{2}{*}{ Incapability of mucking [Slurry] } & Damage of pipe and pump & RE6-4 & \multirow{2}{*}{ T6 } \\
\hline & Blockage of slurry pipe & RE6-5 & \\
\hline \multirow{3}{*}{ Incapability of excavation } & Machine jamming & RE7-1 & \multirow{3}{*}{$\mathrm{T} 7$} \\
\hline & Insufficient torque and thrust force & RE7-2 & \\
\hline & Misalignment/Off-route & RE7-3 & \\
\hline \multicolumn{2}{|c|}{ Water leakage } & RE8 & $\mathrm{T} 8$ \\
\hline
\end{tabular}

\section{Application of CN-Matrix Model}

Risk analyses were performed on three tunneling job sites to compare the four risk analysis models mentioned above: the ITA-Matrix model; the FTA-AHP Matrix model; the STRAM-BN; and the newly proposed CN-Matrix model in this paper. First, to directly compare the job site application results from the four models, the potential risk events and their causal geological risk factors (summarized in Tables 8 and 9), during construction of a shield TBM tunnel, were applied to the ITA-Matrix model and the FTA-AHP Matrix model. The relevance of top risk events (T1-T8) and sub-risk events (RE1-1-RE8) are presented in Table 9. The FTA-AHP Matrix model analyzes risks based on the top risk events, whereas the STRAM-BN and the CN-Matrix model analyze risks based on the sub-risk events. In the case of the ITA-Matrix model, which does not have criteria for the risk event to be analyzed, the risk was analyzed based on the top risk events when it is compared with the 
FTA-AHP Matrix model. On the other hand, when compared with the STRAM-BN and the CN-Matrix model, the risk was analyzed based on the sub-risk events. Furthermore, to use the FTA, the causal relationships between the risk factors and risk events in Figure 4 were restructured into a fault tree for eight top risk events (T1-T8), as shown in Figure 5. Second, the geological risk factors for each job site were identified, and the resulting potential risk events are presented. Then the risk degree was estimated by analyzing the corresponding risk events.

The risk analysis models were applied to two shield TBM under-river tunnel projects (Projects I and II) and one subsea tunnel project (Project III). A slurry shield TBM was utilized for tunneling in Project I, EPB shield TBMs were adopted for tunneling in Projects II and III, respectively. The overview of each project is provided in Table 10, and the longitudinal geological profiles are shown in Figure 6.

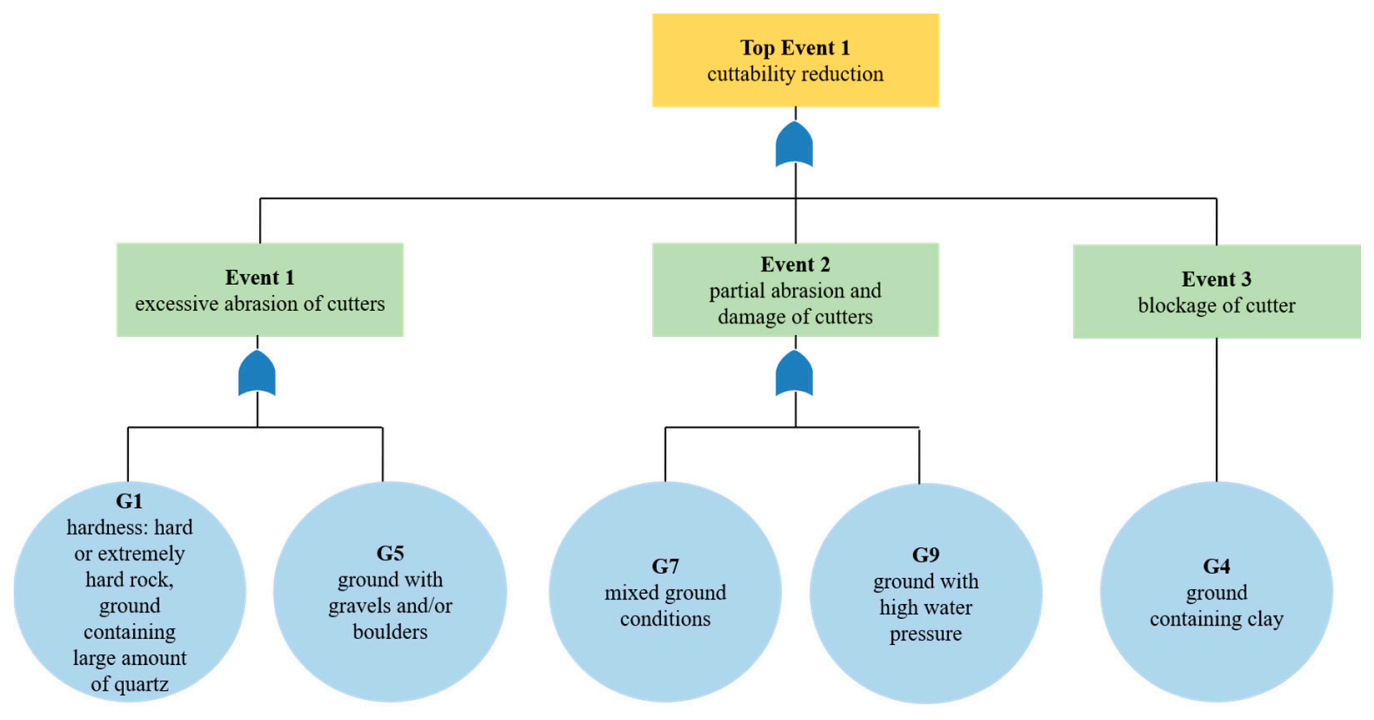

(a)

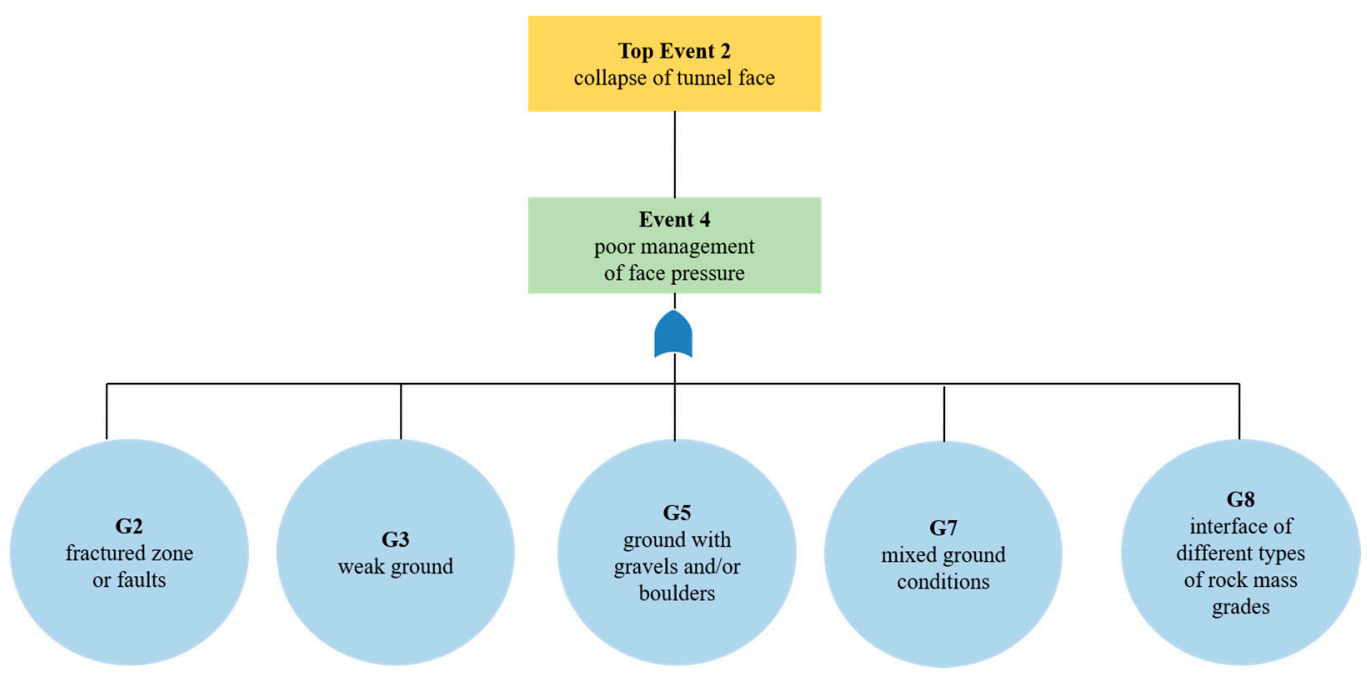

(b)

Figure 5. Cont. 


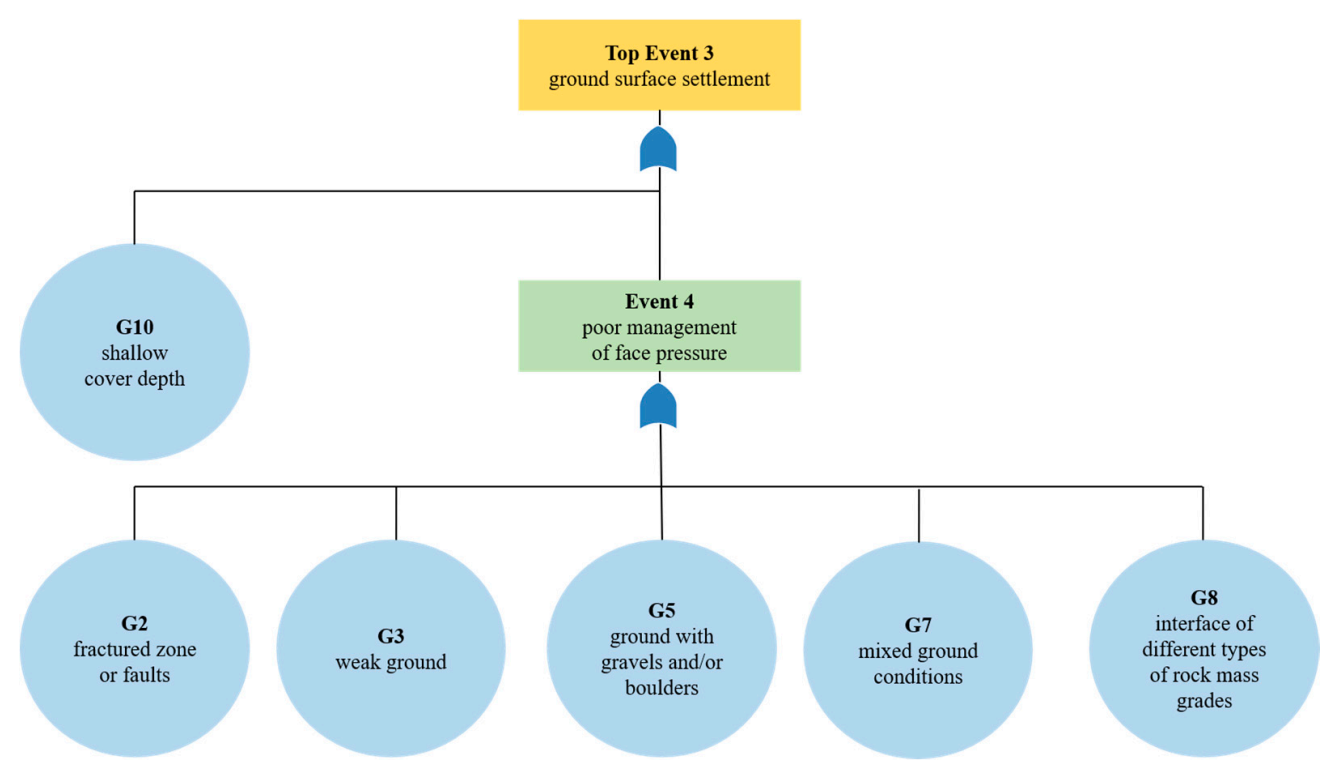

(c)

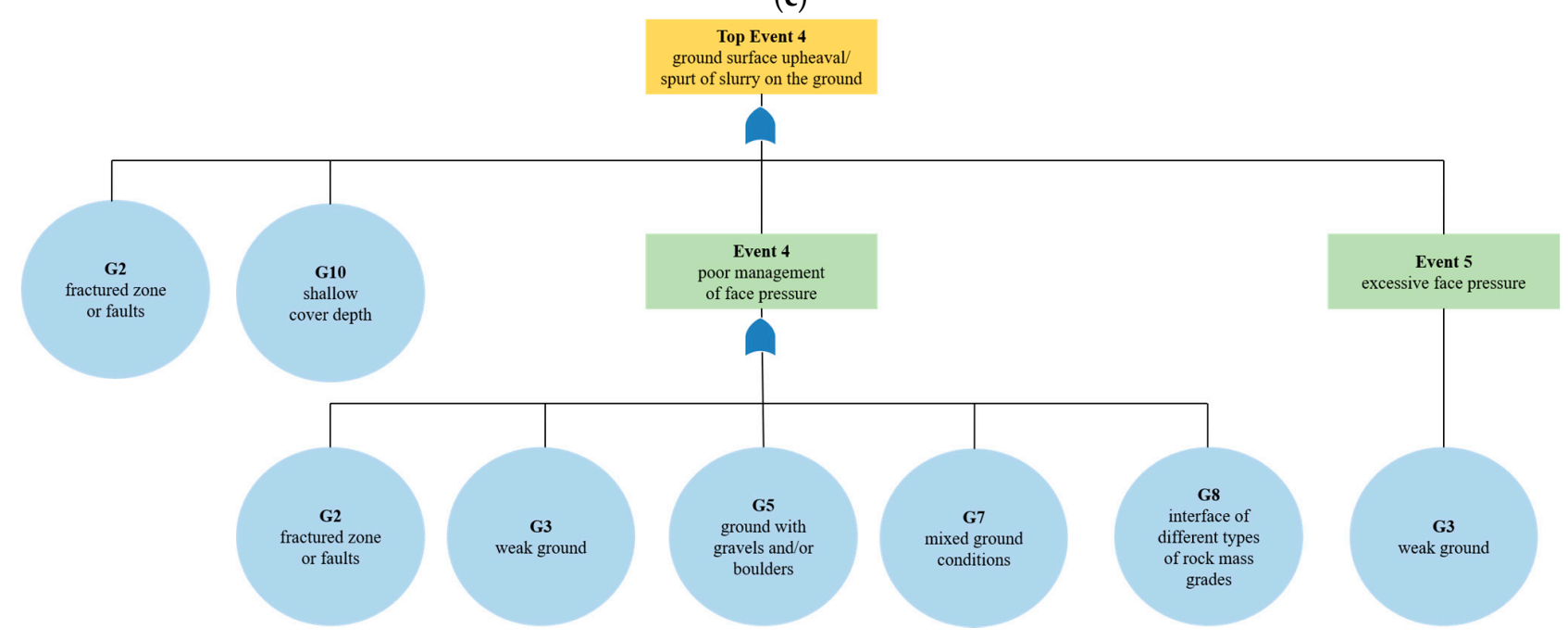

(d)

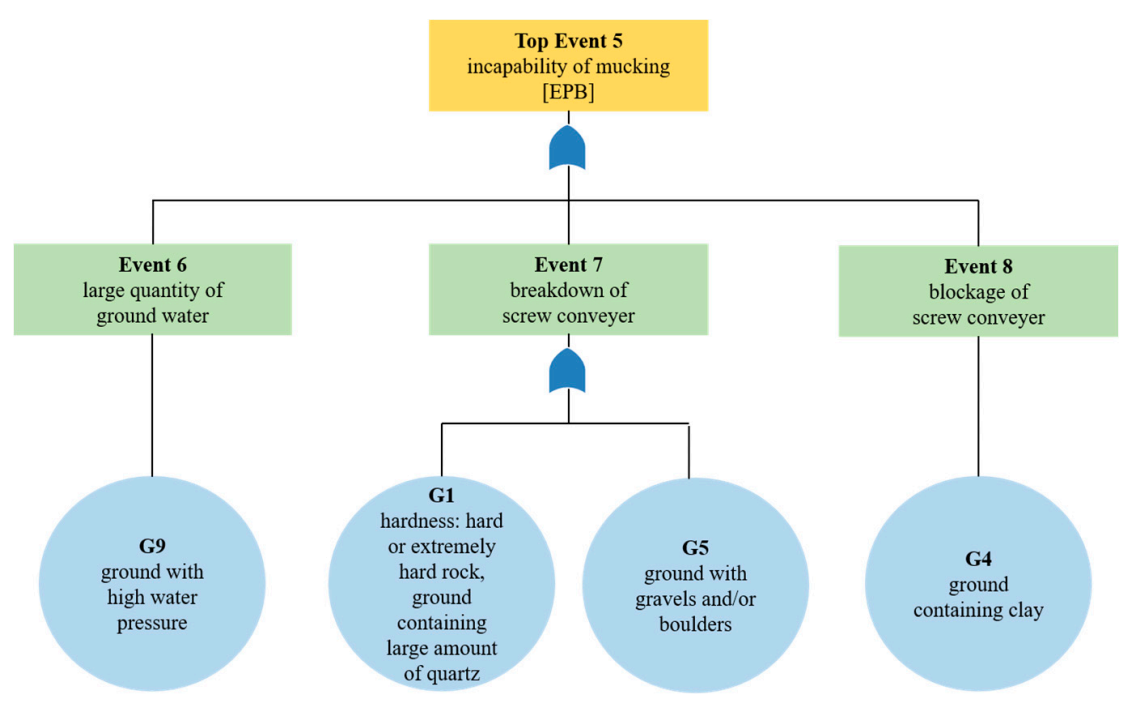

(e)

Figure 5. Cont. 


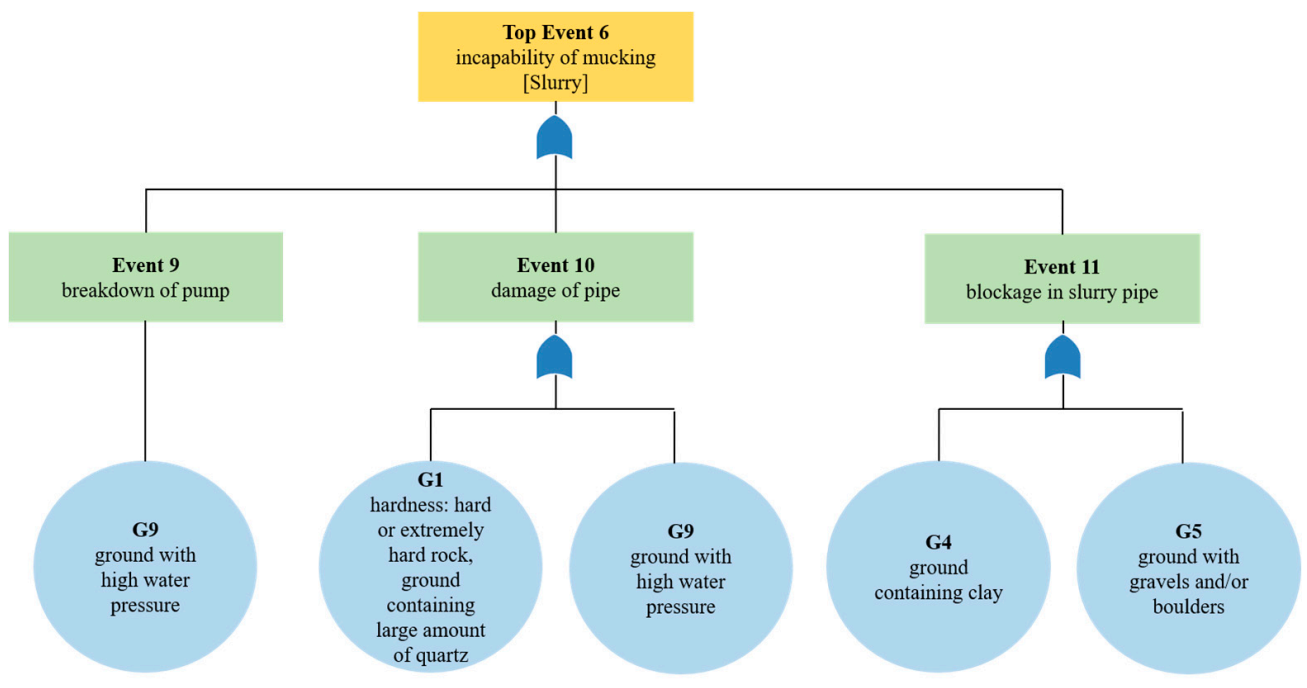

(f)

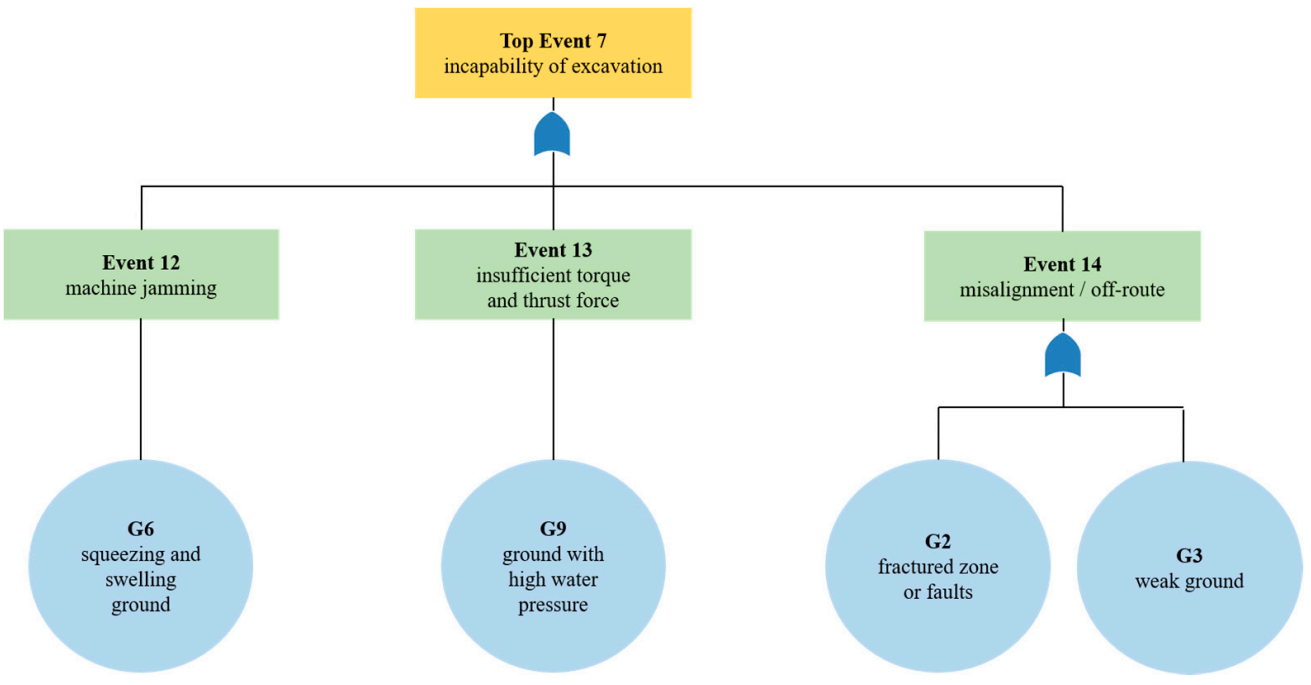

$(\mathrm{g})$

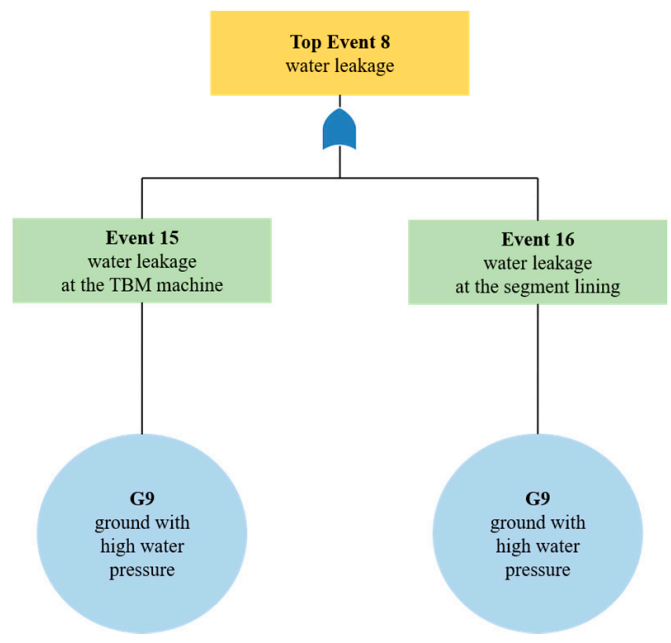

(h)

Figure 5. Restructured Fault Tree for Comparison with STRAM-BN: (a) Cuttability Reduction; (b) Collapse of tunnel face; (c) Ground surface settlement; (d) Ground surface upheaval/Spurt of slurry on the ground; (e) Incapability of mucking [EPB]; (f) Incapability of mucking [Slurry]; (g) Incapability of excavation; (h) Water leakage. 
Table 10. Overview of Three Projects.

\begin{tabular}{cccc}
\hline & Project I & Project II & Project III \\
\hline TBM type & Slurry shield TBM & EPB shield TBM & EPB shield TBM \\
\hline Tunnel length & $1.28 \mathrm{~km}$ & $2.695 \mathrm{~km}$ & $6.297 \mathrm{~km}$ \\
\hline Tunnel diameter & $7.66 \mathrm{~m}$ & $7.8 \mathrm{~m}$ & $9.7 \mathrm{~m}$ \\
\hline Maximum water depth & $\begin{array}{c}\text { About } 35 \mathrm{~m} \\
\text { (Under-river tunnel) }\end{array}$ & $\begin{array}{c}\text { About } 45 \mathrm{~m} \\
\text { (Under-river tunnel) }\end{array}$ & $\begin{array}{c}\text { About } 80 \mathrm{~m} \\
\text { (Subsea tunnel) }\end{array}$ \\
\hline
\end{tabular}

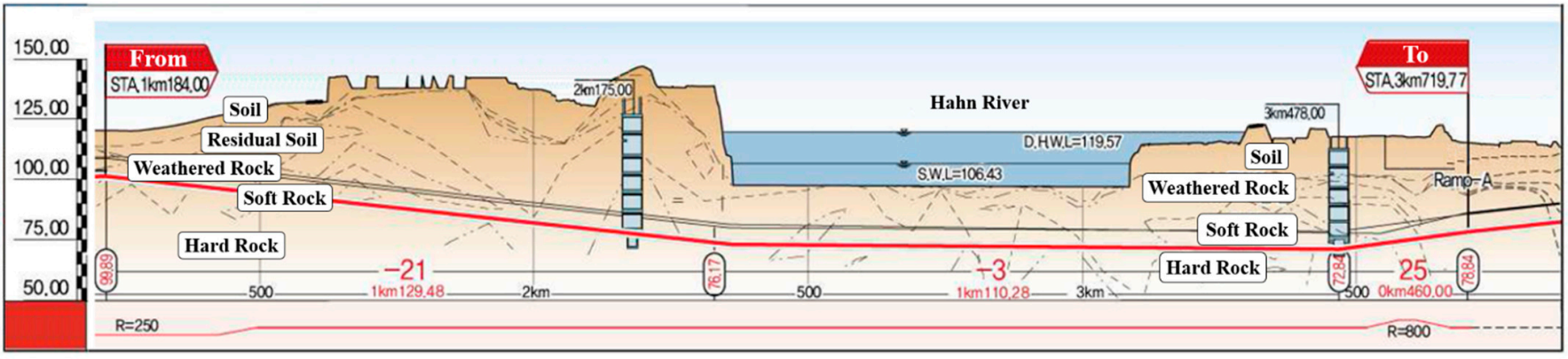

(a)

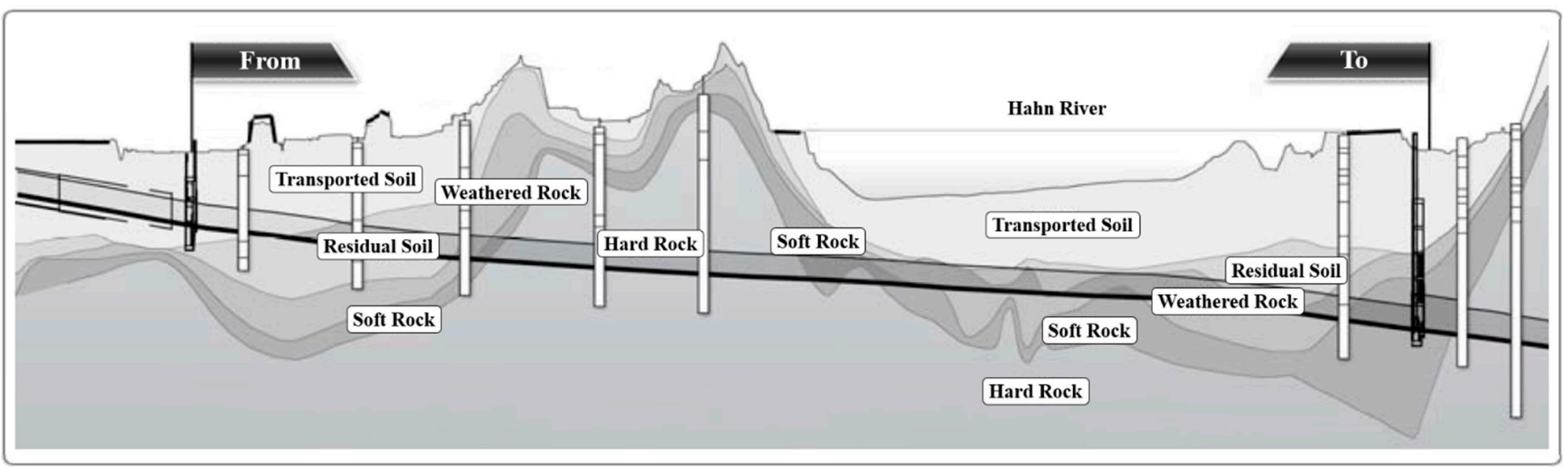

(b)

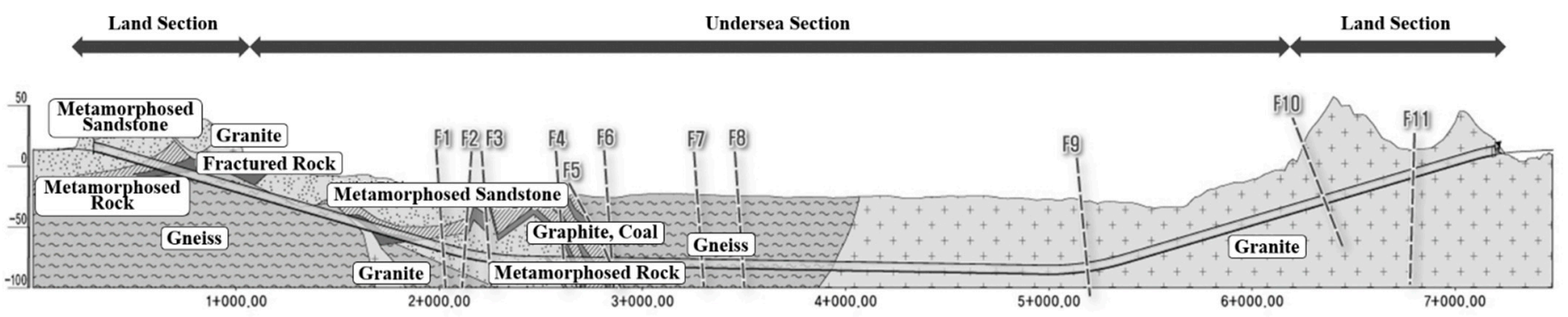

(c)

Figure 6. Longitudinal Geological Profile of Each Project: (a) Project I; (b) Project II; (c) Project III.

\subsection{Modeling Conditions for Real Tunnel Projects}

As for the FTA-AHP Matrix model, the probabilities of eight top risk events (T1-T8) were calculated using the restructured fault tree shown in Figure 5, and the impacts of the eight events were calculated using the AHP. The probability of each risk factor was determined for each job site via a questionnaire survey of TBM tunneling experts. In 
the survey, the probability of the expert's surveys was considered as the central value in the probability range of the evaluated probability score after each expert evaluated the probability score from 1 to 5 points. For example, for a specific risk factor, the probability is determined to be $20 \%$ if the expert evaluates the probability score as 2 . In addition, through a questionnaire survey of TBM tunneling experts, a pairwise comparison matrix was built; the impact of each event was calculated using this matrix. The probability and impact scores were determined according to the score ratings listed in Table 11. The calculation results of the risk degrees for the eight top risk events by applying the FTA-AHP Matrix model to each job site are listed in Table 12.

Table 11. Score Rating of Probability and Impact [14].

\begin{tabular}{cccccc}
\hline Score & Probability Class & Probability & Score & Impact Class & Impact \\
\hline 5 & Very likely & More than $80 \%$ & 5 & Very high & More than 0.16 \\
\hline 4 & Likely & $50-80 \%$ & 4 & High & $0.12-0.16$ \\
\hline 3 & Occasional & $30-50 \%$ & 3 & Moderate & $0.08-0.12$ \\
\hline 2 & Unlikely & $10-30 \%$ & 2 & Low & $0.04-0.08$ \\
\hline 1 & Very unlikely & Below $10 \%$ & 1 & Very low & Below 0.04 \\
\hline
\end{tabular}

In the case of the ITA-Matrix model, the frequency and consequence classes were determined via a questionnaire survey from TBM tunneling experts using the frequency and consequence classifications presented in Tables 1 and 2, respectively. The calculation results of the risk degrees of the ITA-Matrix model for the eight top risk events and the potential sub-risk events caused by the corresponding geological risk factors are listed in Tables 12-15.

When it comes to the STRAM-BN, the conditional probabilities of the potential sub-risk events were determined from the identified geological risk factors, and the countermeasure for each risk event was selected by considering the conditions of each project and the TBM type. The cost of countermeasure was calculated by consulting with the cost estimation specialists in consideration of the direct and indirect cost for implementing the countermeasure for the $20 \mathrm{~m}$ section. The risk degrees for the potential sub-risk events of each job site are listed in Tables 13-15.

With respect to the CN-Matrix model, the probability of occurrence of potential subrisk events caused by the corresponding geological risk factors was determined for each job site via a questionnaire survey of TBM tunneling experts. The survey item corresponding to the probability is related to the sub-risk events caused by the corresponding geological risk factors in the CN-Matrix model, but it is directly related to the geological risk factor in the FTA-AHP Matrix model. The impact of the potential sub-risk events for the downtime caused by each of these sub-risk events was calculated using the AHP. In the FTA-AHP Matrix model, the probability and impact scores were determined based on the score ratings listed in Table 11. The calculation results by applying the CN-Matrix model to each job site are listed in Tables 13-15.

\subsection{Comparison of Risk Analysis Models}

When the FTA-AHP Matrix model was applied, all three job sites showed high degrees of risk (more than III) in cuttability reduction, the collapse of the tunnel face, incapability of mucking, and incapability of excavation events. In Project II, the risk degree of the water leakage event was also high. The ITA-Matrix model indicated that the risk degrees of cuttability reduction, the collapse of the tunnel face, incapability of mucking, and incapability of excavation events were high for all three job sites, which is similar to the FTA-AHP Matrix model. In Projects II and III, the water leakage event was evaluated with a high-risk degree. 
Table 12. Risk Analysis Results using FTA-AHP Matrix Model and ITA-Matrix Model for Each Project.

\begin{tabular}{|c|c|c|c|c|c|c|c|c|c|c|c|c|c|c|c|c|c|c|c|}
\hline \multirow{3}{*}{\multicolumn{2}{|c|}{ Risk Event }} & \multicolumn{6}{|c|}{ Project I } & \multicolumn{6}{|c|}{ Project II } & \multicolumn{6}{|c|}{ Project III } \\
\hline & & \multicolumn{3}{|c|}{$\begin{array}{l}\text { FTA-AHP } \\
\text { Matrix }\end{array}$} & \multicolumn{3}{|c|}{ ITA-Matrix } & \multicolumn{3}{|c|}{$\begin{array}{l}\text { FTA-AHP } \\
\text { Matrix }\end{array}$} & \multicolumn{3}{|c|}{ ITA-Matrix } & \multicolumn{3}{|c|}{$\begin{array}{l}\text { FTA-AHP } \\
\text { Matrix }\end{array}$} & \multicolumn{3}{|c|}{ ITA-Matrix } \\
\hline & & $\begin{array}{l}\text { Probability } \\
\text { Score }\end{array}$ & $\begin{array}{l}\text { Impact } \\
\text { Score }\end{array}$ & $\begin{array}{c}\text { Risk } \\
\text { Score } \\
\text { (Level) }\end{array}$ & Frequency & Consequence & $\begin{array}{l}\text { Risk } \\
\text { Level } \\
1\end{array}$ & $\begin{array}{c}\text { Probability } \\
\text { score }\end{array}$ & $\begin{array}{l}\text { Impact } \\
\text { Score }\end{array}$ & $\begin{array}{c}\text { Risk } \\
\text { Score } \\
\text { (Level) }\end{array}$ & Frequency & Consequence & $\begin{array}{l}\text { Risk } \\
\text { Level } \\
1\end{array}$ & $\begin{array}{l}\text { Probability } \\
\text { Score }\end{array}$ & $\begin{array}{l}\text { Impact } \\
\text { Score }\end{array}$ & $\begin{array}{l}\text { Risk } \\
\text { Score } \\
\text { (Level) }\end{array}$ & Frequency & Consequence & $\begin{array}{c}\text { Risk } \\
\text { Level } \\
1\end{array}$ \\
\hline $\mathrm{T} 1$ & $\begin{array}{l}\text { Cuttability } \\
\text { reduction }\end{array}$ & 4 & 5 & $\begin{array}{l}20 \\
\text { (IV) }\end{array}$ & Likely & Serious & III & 4 & 3 & $\begin{array}{c}12 \\
\text { (III) } \\
\end{array}$ & Occasional & Serious & III & 5 & 3 & $\begin{array}{l}15 \\
\text { (III) }\end{array}$ & Likely & Serious & III \\
\hline $\mathrm{T} 2$ & $\begin{array}{l}\text { Collapse of } \\
\text { tunnel face }\end{array}$ & 4 & 5 & $\begin{array}{l}20 \\
\text { (IV) }\end{array}$ & Occasional & Severe & III & 4 & 5 & $\begin{array}{l}20 \\
\text { (IV) }\end{array}$ & Occasional & Severe & III & 4 & 5 & $\begin{array}{l}20 \\
\text { (IV) }\end{array}$ & Occasional & Severe & III \\
\hline T3 & $\begin{array}{c}\text { Ground } \\
\text { surface } \\
\text { settlement }\end{array}$ & 4 & 1 & $\begin{array}{l}4 \\
\text { (I) }\end{array}$ & Occasional & Considerable & II & 4 & 1 & $\begin{array}{l}4 \\
\text { (I) }\end{array}$ & Unlikely & Considerable & II & 5 & 1 & $\begin{array}{l}5 \\
(\mathrm{I})\end{array}$ & Occasional & Considerable & II \\
\hline $\mathrm{T} 4$ & $\begin{array}{c}\text { Ground } \\
\text { surface up- } \\
\text { heaval/Spurt } \\
\text { of slurry on } \\
\text { the ground } \\
\text { [Slurry] }\end{array}$ & 5 & 1 & $\begin{array}{l}5 \\
\text { (I) }\end{array}$ & Occasional & Considerable & II & 4 & 1 & $\begin{array}{l}4 \\
\text { (I) }\end{array}$ & $\begin{array}{c}\text { Very } \\
\text { unlikely }\end{array}$ & Insignificant & I & 5 & 1 & $\begin{array}{l}5 \\
(\mathrm{I})\end{array}$ & $\begin{array}{c}\text { Very } \\
\text { unlikely }\end{array}$ & Insignificant & $\mathrm{I}$ \\
\hline $\mathrm{T} 5$ & $\begin{array}{c}\text { Incapability } \\
\text { of mucking } \\
\text { [EPB] }\end{array}$ & 3 & 1 & $\begin{array}{l}3 \\
(\mathrm{I})\end{array}$ & $\begin{array}{c}\text { Very } \\
\text { unlikely }\end{array}$ & Considerable & $\mathrm{I}$ & 2 & 5 & $\begin{array}{l}10 \\
\text { (III) }\end{array}$ & Occasional & Serious & III & 4 & 5 & $\begin{array}{l}20 \\
\text { (IV) }\end{array}$ & Occasional & Serious & III \\
\hline T6 & $\begin{array}{c}\text { Incapability } \\
\text { of mucking } \\
\text { [Slurry] }\end{array}$ & 3 & 4 & $\begin{array}{l}12 \\
\text { (III) }\end{array}$ & Occasional & Serious & III & 3 & 1 & $\begin{array}{l}3 \\
\text { (I) }\end{array}$ & $\begin{array}{c}\text { Very } \\
\text { unlikely }\end{array}$ & Considerable & I & 4 & 1 & $\begin{array}{l}4 \\
\text { (I) }\end{array}$ & $\begin{array}{c}\text { Very } \\
\text { unlikely }\end{array}$ & Considerable & $\mathrm{I}$ \\
\hline $\mathrm{T} 8$ & $\begin{array}{c}\text { Water } \\
\text { leakage }\end{array}$ & 1 & 3 & $\begin{array}{l}3 \\
\text { (I) } \\
\end{array}$ & Occasional & Considerable & II & 3 & 4 & $\begin{array}{l}12 \\
\text { (III) }\end{array}$ & Likely & Serious & III & 3 & 3 & $\begin{array}{c}9 \\
\text { (II) }\end{array}$ & Likely & Severe & IV \\
\hline
\end{tabular}

${ }^{1}$ Risk level: Negligible (I), Acceptable (II), Unwanted (III), Unacceptable (IV). 
Table 13. Risk Analysis Results using STRAM-BN, CN-Matrix Model, and ITA-Matrix Model for Project I.

\begin{tabular}{|c|c|c|c|c|c|c|c|c|c|c|}
\hline & \multirow[b]{2}{*}{ Geological Risk Factor } & \multirow{2}{*}{\multicolumn{2}{|c|}{ Risk Event }} & \multirow{2}{*}{$\begin{array}{c}\text { STRAM-BN } \\
\begin{array}{c}\text { Degree of Risk } \\
\text { (Risk Level) }\end{array}\end{array}$} & \multicolumn{3}{|c|}{ CN-Matrix } & \multicolumn{3}{|c|}{ ITA-Matrix } \\
\hline & & & & & $\begin{array}{c}\text { Probability } \\
\text { Score }\end{array}$ & $\begin{array}{c}\text { Impact } \\
\text { Score }\end{array}$ & $\begin{array}{c}\text { Risk Score } \\
\text { (Level) }\end{array}$ & Frequency & Consequence & Risk Level \\
\hline \multirow[b]{2}{*}{ G1 } & \multirow{2}{*}{$\begin{array}{l}\text { Hardness: hard or extremely } \\
\text { hard rock, ground containing } \\
\text { large amount of quartz }\end{array}$} & RE1-1 & $\begin{array}{c}\text { Cuttability reduction } \\
\text { (Excessive abrasion of cutters) }\end{array}$ & 24.64 (II) & 4 & 3 & 12 (III) & Likely & Serious & III \\
\hline & & RE6-4 & $\begin{array}{c}\text { Incapability of mucking } \\
\text { (Damage of pipe and pump) }\end{array}$ & 25.14 (II) & 3 & 4 & 12 (III) & Occasional & Serious & III \\
\hline \multirow[b]{2}{*}{ G2 } & \multirow[b]{2}{*}{ Fractured zone or faults } & RE2 & Collapse of tunnel face & 33.43 (III) & 1 & 5 & $5(\mathrm{I})$ & Unlikely & Severe & III \\
\hline & & RE7-3 & $\begin{array}{l}\text { Incapability of excavation } \\
\text { (Misalignment/Off-route) }\end{array}$ & $4.22(\mathrm{I})$ & 2 & 1 & 2 (I) & Unlikely & Serious & II \\
\hline \multirow{2}{*}{ G4 } & \multirow{2}{*}{ Ground containing clay } & RE1-3 & $\begin{array}{l}\text { Cuttability reduction } \\
\text { (Blockage of cutter) }\end{array}$ & 19.34 (II) & 4 & 2 & 8 (II) & Occasional & Serious & III \\
\hline & & RE6-5 & $\begin{array}{l}\text { Incapability of mucking } \\
\text { (Blockage of slurry pipe) }\end{array}$ & 10.21 (II) & 2 & 2 & 4 (I) & Unlikely & Serious & II \\
\hline \multirow[t]{2}{*}{ G7 } & \multirow[t]{2}{*}{ Mixed ground conditions } & RE1-2 & $\begin{array}{c}\text { Cuttability reduction } \\
\text { (Partial abrasion and damage of cutters) }\end{array}$ & 15.04 (II) & 3 & 3 & 9 (II) & Likely & Serious & III \\
\hline & & RE2 & Collapse of tunnel face & 33.43 (III) & 1 & 5 & $5(\mathrm{I})$ & Unlikely & Severe & III \\
\hline \multirow{4}{*}{\multicolumn{2}{|c|}{ G9 Ground with high water pressure }} & RE1-2 & $\begin{array}{c}\text { Cuttability reduction } \\
\text { (Partial abrasion and damage of cutters) }\end{array}$ & 17.28 (II) & 3 & 3 & 9 (II) & Unlikely & Serious & II \\
\hline & & RE6-4 & $\begin{array}{c}\text { Incapability of mucking } \\
\text { (Damage of pipe and pump) }\end{array}$ & 36.79 (III) & 3 & 4 & 12 (III) & Occasional & Serious & III \\
\hline & & RE7-2 & $\begin{array}{c}\text { Incapability of excavation } \\
\text { (Insufficient torque and thrust force) }\end{array}$ & 88.57 (IV) & 2 & 5 & 10 (III) & Unlikely & Severe & III \\
\hline & & RE8 & Water leakage & $6.62(\mathrm{I})$ & 2 & 2 & $4(\mathrm{I})$ & Unlikely & Serious & II \\
\hline
\end{tabular}

${ }^{1}$ Unit: $\times 10^{3}$ US dollars. 
Table 14. Risk Analysis Results using STRAM-BN, CN-Matrix Model, and ITA-Matrix Model for Project II.

\begin{tabular}{|c|c|c|c|c|c|c|c|c|c|c|c|c|c|}
\hline \multirow{3}{*}{\multicolumn{2}{|c|}{$\begin{array}{c}\text { Geological Risk } \\
\text { Factor }\end{array}$}} & & \multirow{3}{*}{ Risk Event } & \multicolumn{5}{|c|}{ EPB-Open } & \multicolumn{5}{|c|}{ EPB-Closed } \\
\hline & & & & \multirow{2}{*}{$\begin{array}{c}\text { STRAM-BN } \\
\text { Degree of } \\
\text { Risk }^{1} \\
\text { (Risk Level) }\end{array}$} & \multicolumn{3}{|c|}{ CN-Matrix } & \multirow{2}{*}{$\begin{array}{l}\text { ITA-Matrix } \\
\text { Risk Level }\end{array}$} & \multirow{2}{*}{$\begin{array}{c}\text { STRAM-BN } \\
\text { Degree of }^{\text {Risk }^{1}} \\
\text { (Risk Level) }^{-}\end{array}$} & \multicolumn{3}{|c|}{$\mathrm{CN}$-Matrix } & \multirow{2}{*}{$\begin{array}{l}\text { ITA-Matrix } \\
\text { Risk Level }\end{array}$} \\
\hline & & & & & $\begin{array}{l}\text { Probability } \\
\text { Score }\end{array}$ & $\begin{array}{l}\text { Impact } \\
\text { Score }\end{array}$ & $\begin{array}{l}\text { Risk Score } \\
\text { (Level) }\end{array}$ & & & $\begin{array}{l}\text { Probability } \\
\text { Score }\end{array}$ & $\begin{array}{l}\text { Impact } \\
\text { Score }\end{array}$ & $\begin{array}{c}\text { Risk } \\
\text { Score } \\
\text { (Level) }\end{array}$ & \\
\hline \multirow[b]{2}{*}{ G2 } & \multirow{2}{*}{$\begin{array}{l}\text { Fractured zone } \\
\quad \text { or faults }\end{array}$} & RE2 & Collapse of tunnel face & 123.52 (IV) & 4 & 5 & 20 (IV) & IV & 68.62 (III) & 2 & 5 & 10 (III) & III \\
\hline & & RE7-3 & $\begin{array}{l}\text { Incapability of excavation } \\
\text { (Misalignment/Off-route) }\end{array}$ & $3.98(\mathrm{I})$ & 2 & 1 & $2(\mathrm{I})$ & II & $3.98(\mathrm{I})$ & 2 & 1 & 2 (I) & II \\
\hline \multirow{2}{*}{ G4 } & \multirow{2}{*}{$\begin{array}{l}\text { Ground } \\
\text { containing clay }\end{array}$} & RE1-3 & $\begin{array}{l}\text { Cuttability reduction } \\
\text { (Blockage of cutter) }\end{array}$ & $9.40(\mathrm{I})$ & 2 & 2 & 4 (I) & II & 14.65 (II) & 3 & 2 & 6 (II) & II \\
\hline & & RE6-3 & $\begin{array}{c}\text { Incapability of mucking } \\
\text { (Blockage of screw conveyer) }\end{array}$ & $6.08(\mathrm{I})$ & 2 & 1 & 2 (I) & II & $6.64(\mathrm{I})$ & 2 & 1 & 2 (I) & II \\
\hline \multirow[t]{2}{*}{ G7 } & \multirow[t]{2}{*}{$\begin{array}{l}\text { Mixed ground } \\
\text { conditions }\end{array}$} & RE1-2 & $\begin{array}{c}\text { Cuttability reduction } \\
\text { (Partial abrasion and damage } \\
\text { of cutters) }\end{array}$ & 18.61 (II) & 3 & 2 & 6 (II) & III & 20.01 (II) & 3 & 2 & 6 (II) & III \\
\hline & & RE2 & Collapse of tunnel face & 123.52 (IV) & 4 & 5 & 20 (IV) & IV & 68.62 (III) & 2 & 5 & 10 (III) & III \\
\hline \multirow{4}{*}{ G9 } & \multirow{4}{*}{$\begin{array}{l}\text { Ground with } \\
\text { high water } \\
\text { pressure }\end{array}$} & RE1-2 & $\begin{array}{c}\text { Cuttability reduction } \\
\text { (Partial abrasion and damage } \\
\text { of cutters) }\end{array}$ & 18.61 (II) & 3 & 2 & 6 (II) & III & 22.47 (II) & 4 & 2 & 8 (II) & III \\
\hline & & RE6-1 & $\begin{array}{l}\text { Incapability of mucking } \\
\text { (Large quantity of } \\
\text { ground water) }\end{array}$ & 93.84 (IV) & 4 & 5 & 20 (IV) & IV & 64.97 (III) & 3 & 5 & 15 (III) & III \\
\hline & & RE7-2 & $\begin{array}{c}\text { Incapability of excavation } \\
\text { (Insufficient torque and } \\
\text { thrust force) }\end{array}$ & 83.24 (IV) & 2 & 5 & 10 (III) & III & 83.24 (IV) & 2 & 5 & 10 (III) & III \\
\hline & & RE8 & Water leakage & 31.38 (III) & 3 & 3 & 9 (II) & IV & 10.61 (II) & 2 & 3 & 6 (II) & III \\
\hline
\end{tabular}

${ }^{1}$ Unit: $\times 10^{3}$ US dollars. 
Table 15. Risk Analysis Results using STRAM-BN, CN-Matrix Model, and ITA-Matrix Model for Project III.

\begin{tabular}{|c|c|c|c|c|c|c|c|c|c|c|c|c|c|}
\hline & \multirow{3}{*}{ Geological Risk Factor } & & \multirow{3}{*}{ Risk Event } & \multicolumn{5}{|c|}{ EPB-Open } & \multicolumn{5}{|c|}{ EPB-Closed } \\
\hline & & & & \multirow{2}{*}{$\begin{array}{c}\text { STRAM-BN } \\
\text { Degree of } \\
\text { Risk }^{1} \\
\text { (Risk Level) }\end{array}$} & \multicolumn{3}{|c|}{ CN-Matrix } & \multirow{2}{*}{$\begin{array}{c}\begin{array}{c}\text { ITA- } \\
\text { Matrix }\end{array} \\
\begin{array}{c}\text { Risk } \\
\text { Level }\end{array}\end{array}$} & \multirow{2}{*}{$\begin{array}{c}\text { STRAM-BN } \\
\text { Degree of }^{\text {Risk }^{1}} \\
\text { (Risk Level) }^{-1}\end{array}$} & \multicolumn{3}{|c|}{ CN-Matrix } & \multirow{2}{*}{$\begin{array}{c}\begin{array}{c}\text { ITA- } \\
\text { Matrix }\end{array} \\
\text { Risk } \\
\text { Level }\end{array}$} \\
\hline & & & & & $\begin{array}{l}\text { Probability } \\
\text { Score }\end{array}$ & $\begin{array}{l}\text { Impact } \\
\text { Score }\end{array}$ & $\begin{array}{l}\text { Risk Score } \\
\text { (Level) }\end{array}$ & & & $\begin{array}{l}\text { Probability } \\
\text { Score }\end{array}$ & $\begin{array}{l}\text { Impact } \\
\text { Score }\end{array}$ & $\begin{array}{c}\text { Risk } \\
\text { Score } \\
\text { (Level) }\end{array}$ & \\
\hline \multirow{2}{*}{ G1 } & \multirow{2}{*}{$\begin{array}{l}\text { Hardness: hard or extremely } \\
\text { hard rock, ground containing } \\
\text { large amount of quartz }\end{array}$} & RE1-1 & $\begin{array}{l}\text { Cuttability reduction } \\
\text { (Excessive abrasion } \\
\text { of cutters) }\end{array}$ & 26.96 (II) & 4 & 2 & 8 (II) & III & 31.52 (III) & 5 & 2 & 10 (III) & III \\
\hline & & RE6-2 & $\begin{array}{l}\text { Incapability of mucking } \\
\text { (Breakdown of } \\
\text { screw conveyer) }\end{array}$ & 24.87 (II) & 2 & 2 & $4(\mathrm{I})$ & III & 27.07 (II) & 2 & 2 & $4(\mathrm{I})$ & III \\
\hline \multirow[b]{2}{*}{ G2 } & \multirow[b]{2}{*}{ Fractured zone or faults } & RE2 & Collapse of tunnel face & 112.17 (IV) & 4 & 5 & 20 (IV) & IV & 62.31 (III) & 2 & 5 & 10 (III) & III \\
\hline & & RE7-3 & $\begin{array}{l}\text { Incapability of excavation } \\
\text { (Misalignment/Off-route) }\end{array}$ & 3.77 (I) & 2 & 1 & $2(\mathrm{I})$ & II & 3.77 (I) & 2 & 1 & 2 (I) & II \\
\hline \multirow{2}{*}{ G4 } & \multirow{2}{*}{ Ground containing clay } & RE1-3 & $\begin{array}{c}\text { Cuttability reduction } \\
\text { (Blockage of cutter) }\end{array}$ & 7.00 (I) & 2 & 1 & $2(\mathrm{I})$ & II & 10.92 (II) & 3 & 1 & $3(\mathrm{I})$ & II \\
\hline & & RE6-3 & $\begin{array}{c}\text { Incapability of mucking } \\
\text { (Blockage of screw conveyer) }\end{array}$ & $4.53(\mathrm{I})$ & 2 & 1 & $2(\mathrm{I})$ & II & 4.94 (I) & 2 & 1 & 2 (I) & II \\
\hline \multirow[t]{2}{*}{ G7 } & \multirow[t]{2}{*}{ Mixed ground conditions } & RE1-2 & $\begin{array}{c}\text { Cuttability reduction } \\
\text { (Partial abrasion and damage } \\
\text { of cutters) }\end{array}$ & 18.56 (II) & 3 & 2 & 6 (II) & III & 21.01 (II) & 3 & 2 & 6 (II) & III \\
\hline & & RE2 & Collapse of tunnel face & 112.17 (IV) & 4 & 5 & 20 (IV) & IV & 62.31 (III) & 2 & 5 & 10 (III) & III \\
\hline G8 & $\begin{array}{l}\text { Interface of different types of } \\
\text { rock mass grades }\end{array}$ & RE2 & Collapse of tunnel face & 112.17 (IV) & 4 & 5 & 20 (IV) & III & 62.31 (III) & 2 & 5 & 10 (III) & III \\
\hline \multirow{4}{*}{ G9 } & \multirow{4}{*}{$\begin{array}{l}\text { Ground with high } \\
\text { water pressure }\end{array}$} & RE1-2 & $\begin{array}{l}\text { Cuttability reduction } \\
\text { (Partial abrasion and damage } \\
\text { of cutters) }\end{array}$ & 18.56 (II) & 3 & 2 & 6 (II) & III & 23.46 (II) & 4 & 2 & 8 (II) & III \\
\hline & & RE6-1 & $\begin{array}{c}\text { Incapability of mucking } \\
\text { (Large quantity of } \\
\text { ground water) }\end{array}$ & 116.26 (IV) & 4 & 5 & 20 (IV) & IV & 80.49 (IV) & 3 & 5 & 15 (III) & IV \\
\hline & & RE7-2 & $\begin{array}{c}\text { Incapability of excavation } \\
\text { (Insufficient torque and } \\
\text { thrust force) }\end{array}$ & 191.20 (IV) & 2 & 5 & 10 (III) & III & 191.20 (IV) & 2 & 5 & 10 (III) & III \\
\hline & & RE8 & Water leakage & 29.75 (II) & 3 & 3 & 9 (II) & IV & 10.06 (II) & 2 & 3 & 6 (II) & III \\
\hline
\end{tabular}

${ }^{1}$ Unit: $\times 10^{3}$ US dollars. 
When the STRAM-BN was applied, the risk degree of collapse of the tunnel face was high owing to G2 (fractured zone or faults) and G7 (mixed ground conditions), which existed in all the job sites. In addition, the risk degrees of incapability of mucking (large quantity of groundwater/damage of pipe and pump) and incapability of excavation (insufficient torque and thrust force) were high owing to G9 (ground with high water pressure) for all three job sites because all three job sites are subsea/under-river tunnels. In Project III, the risk degree of collapse of the tunnel face owing to G8 (interface of different types of rock mass grades) was also high. In general, the risk degrees of Project I, which is a slurry shield TBM site, were lower than those of Projects II and III, which are EPB shield TBM sites.

When the CN-Matrix model was applied, the results of the risk degrees were similar to the STRAM-BN for each potential sub-risk event caused by the corresponding geological risk factors. However, the risk degree of the cuttability reduction was also high owing to G1 (hard or extremely hard rock/ground containing a large amount of quartz) in Project I. However, in Project I, the risk degrees of collapse of the tunnel face owing to G2 (fractured zone or faults) and G7 (mixed ground conditions) were evaluated to be low. In Project II, the risk degree of water leakage owing to G9 (ground with high water pressure) was found to be low.

As mentioned earlier, a direct comparison between the Matrix models and the Bayesian model is not feasible. The risk degree is obtained considering the top risk events in the FTA-AHP Matrix model, whereas the STRAM-BN and the CN-Matrix model determine the risk degree on the sub-risk event for each geological risk factor. In a simple comparison based on top risk events, except for the cuttability reduction event, which showed a highrisk degree in the Matrix models, all four models demonstrated a high degree of risk for the collapse of the tunnel face, incapability of mucking, and incapability of excavation events.

As presented in Table 12, in the case of event T4 (ground surface upheaval/spurt of slurry on the ground) in Project I, and events T3 (ground surface settlement) and T4 in Project III, the probability score is the highest (5), while the impact score is the lowest (1) in the FTA-AHP Matrix model, resulting in a risk degree (probability score $\times$ impact score) of 5 points. Then, the risk level is Negligible (I) of the lowest risk level in Figure 2. However, the risk level will increase up to Unwanted (III) if the ITA-Matrix model is applied even with the same frequency and consequence classes. In other words, it is possible for the FTAAHP Matrix model to underestimate the risk degrees compared to the ITA Matrix model. It is believed that the risk level proposed by the ITA-Matrix model is more reasonable in this case because if the consequence of the event is disastrous despite the low frequency of occurrence, it might be more rational to assign a higher risk level than Negligible (I).

As for the event of the collapse of the tunnel face owing to G2 (fractured zone or faults), and G7 (mixed ground conditions) in Project I (see Table 13), the risk level obtained by the CN-Matrix model was significantly lower than that obtained by the other two models. This is because the CN-Matrix model evaluates an event as a low-risk level even when only one of the categories ranks as the highest class and the other ranks as the lowest class similar to the FTA-AHP Matrix model. From these results, it is rational to increase the risk levels of the CN-Matrix model. Some guidelines used the weighting scores for probability from the scale of 1 to 5 points to the scale of 0.05 to 0.8 points $(0.05,0.1,0.2,0.4$, and 0.8$)$ and for impact from the scale of 1 to 5 points to the scale of 0.1 to 0.9 points $(0.1,0.3,0.5,0.7$, and 0.9) [1,2]. However, the guidelines cannot perfectly address the underestimating problem yet. Therefore, the $\mathrm{CN}$-Matrix model modifies the weighting scores for both probability and impact identically on the scale of 0.05 to 0.8 points $(0.05,0.1,0.2,0.4$, and 0.8$)$ to overcome the underestimation. Moreover, because of the difficulty in calculating the risk levels by multiplying the decimal point of the weighting scores, the integers of the weighting scores on the scale of 1 to 11 points $(1,2,4,7$, and 11) are also proposed. For this purpose, it is recommended in this paper to change the weighting scores for both probability and impact of the sub-risk events in the CN-Matrix model from the scale of 1 to 5 points to the scale of 
either 0.05 to 0.8 points $(0.05,0.1,0.2,0.4$, and 0.8$)$ or 1 to 11 points $(1,2,4,7$, and 11$)$ as shown in Figure 7.

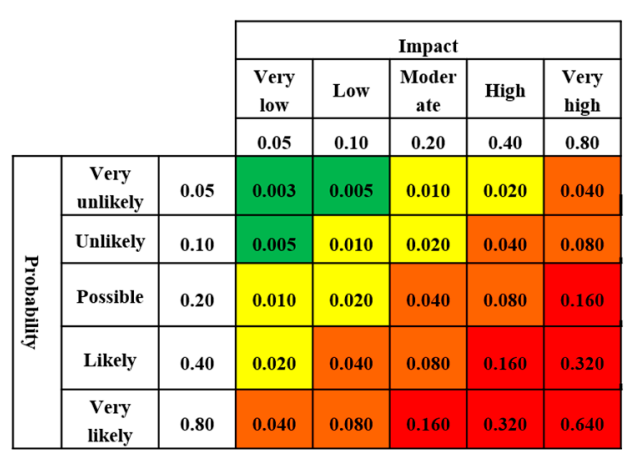

(a)
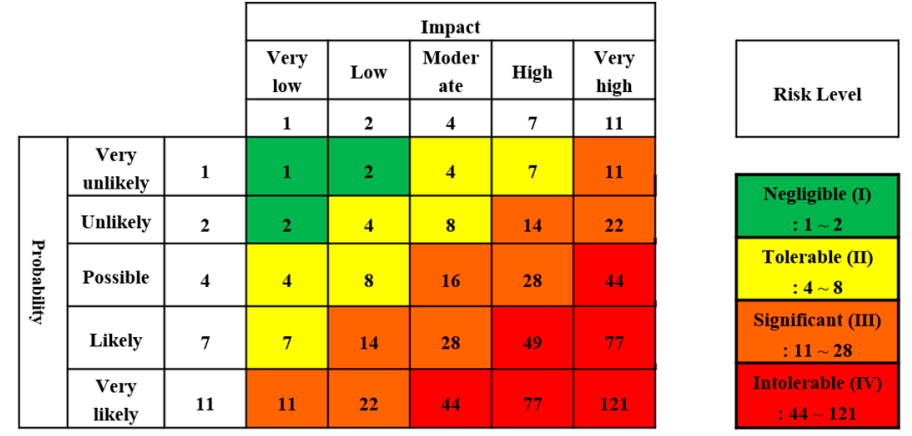

(b)

Figure 7. CN-Matrix Models: (a) Example 1; (b) Example 2.

In summary, the CN-Matrix model is an advanced version of the ITA-Matrix model and the FTA-AHP Matrix model, which is easily applicable to actual tunneling job sites compared to the STRAM-BN. To prevent underestimating when only one of the categories ranks as the highest class and the other ranks as the lowest class, the weighting scores for both probability and impact of the sub-risk events are modified in this model from the scale of 1 to 5 points to the scale of either 0.05 to 0.8 points $(0.05,0.1,0.2,0.4$, and 0.8$)$ or 1 to 11 points $(1,2,4,7$, and 11). Furthermore, the impact of this model is determined based on the relative downtimes caused by each risk event, which is easier to apply in practice rather than estimating the cost of countermeasures.

\section{Conclusions}

In the present study, three tunnel risk analysis models (ITA-Matrix model, FTA-AHP Matrix model, and STRAM-BN), which are applicable to actual shield TBM tunnels, were compared in terms of their advantages and disadvantages. Based on the comparison and analysis results, an improved matrix model, a causal network-based risk matrix model (CN-Matrix model), was proposed. This new model complements the disadvantages and exploits the advantages of the three existing models. The conclusions of this study are as follows.

1. The ITA-Matrix model easily estimates the degree of risk, but its disadvantage is that it is a qualitative analysis/assessment model. The FTA-AHP Matrix model is a quantitative analysis / assessment model, but there are questions on the endowed weighting scores, which range from 1 to 5 for both the probability and impact categories. Furthermore, the current FTA-AHP Matrix model can be applied only in the design stage because it is difficult for this model to reflect the ground conditions of the job site due to its inability to estimate the degree of risk events caused by the corresponding geological risk factors.

2. The STRAM-BN, which uses the Bayesian network, can produce more reasonable results because this model estimates the degree of risk by using the cost of countermeasure on the designated job site; however, the disadvantage is that it is difficult to obtain this cost for a given site. Unlike the FTA-AHP Matrix model, the STRAM-BN has the advantage that it can be used for risk analysis in the construction stage as well as in the design stage because it can estimate the risk degree of sub-risk events caused by the corresponding geological risk factors.

3. According to the results of the comparative analysis for the three existing risk analysis models, this study proposes a new risk matrix model named the CN-Matrix model, which is a modified and improved version of the FTA-AHP Matrix model, by complementing the disadvantages of each model and exploiting their advantages. The 
CN-Matrix model can perform a risk analysis for sub-risk events in the same way as the STRAM-BN. In addition, the newly developed model can analyze risks even in the construction stage as well as in the design stage because it estimates the risk degree of sub-risk events caused by the corresponding geological risk factors, which is similar to the STRAM-BN.

4. This study proposed to change the weighting scores of the probability of the subrisk event as well as its impact so that the change can address the underestimating problems. Furthermore, the impact of this model is determined based on the relative downtimes caused by each risk event, which is easier to apply in practice rather than estimating the cost of countermeasures. Thus, the improved CN-Matrix model is more reliable and robust than the three existing models.

Although this paper introduces a newly developed risk analysis model that exploits advantages of the previous conventional risk analysis models (i.e., ITA-Matrix model, FTA-AHP Matrix model, and STRAM-BN), it has some limitations. First, this study is entirely based on qualitative risk factors rather than quantitative ones. Because all of the conventional risk analysis models utilize the qualitative risk factors, the $\mathrm{CN}$-Matrix model deals with risks for qualitative determination in order to compare with the conventional risk analysis models in the same manner. This lack of quantification may make it difficult to analyze risks during real-time construction. Second, since the probability of each risk factor and the impact of each event were determined for each job site via a questionnaire survey of TBM tunneling experts, the survey can be biased by respondent's knowledge and experience.

In the follow-up research, the risk analysis model will be improved to overcome the upper mentioned limitations by considering quantitative risk factors and/or by adopting advanced data analysis technologies such as the machine learning algorithm. Moreover, it will be possible to improve objectivity and reliability of decision-making, which can also enable the automatic operation of TBM.

Author Contributions: Conceptualization, I.-M.L. and H.C. (Heeyoung Chung); Writing-original draft preparation, H.C. (Heeyoung Chung) and J.P.; Writing-review and editing, B.-K.K. and K.K.; Data curation, H.C. (Heeyoung Chung) and K.K.; Methodology, B.-K.K.; Investigation, H.C. (Heeyoung Chung) and J.P.; Supervision, I.-M.L. and H.C. (Hangseok Choi); Project administration, I.-M.L. and H.C. (Hangseok Choi); Funding acquisition, I.-M.L. and H.C. (Hangseok Choi). All authors have read and agreed to the published version of the manuscript.

Funding: This research was conducted with the support of the "National R\&D Project for Smart Construction Technology (No.20SMIP-A158708-01)" funded by the Korea Agency for Infrastructure Technology Advancement under the Ministry of Land, Infrastructure.

Institutional Review Board Statement: Not applicable.

Informed Consent Statement: Not applicable.

Data Availability Statement: Not applicable.

Acknowledgments: Management support was provided by Korea Expressway Corporation and is gratefully acknowledged.

Conflicts of Interest: The authors declare no conflict of interest.

\section{References}

1. Sharafat, A.; Latif, K.; Seo, J. Risk analysis of TBM tunneling projects based on generic bow-tie risk analysis approach in difficult ground conditions. Tunn. Undergr. Space Technol. 2021, 111, 103860. [CrossRef]

2. Centers for Medicare \& Medicaid Services. XLC Risk Management Guidance and Risk Register Instructions Version 2; Office of Information Services, Centers for Medicare \& Medicaid Services: Baltimore, MD, USA, 2014.

3. Project Management Institute. PMBOK Guide, 5th ed.; Project Management Institute, Inc.: Newtown Square, PA, USA, 2013.

4. Tasmanian Government. Project Management Guidelines; Office of eGovernment, Department of Premier and Cabinet, Hobart: Tasmania, Australia, 2011.

5. Land Transport Authority. Construction Safety Handbook; Land Transport Authority: Singapore, 2012. 
6. Land Transport Authority. Safety, Health and Environment (General Specification Appendix A); Land Transport Authority: Singapore, 2018.

7. WSP I Parsons Brinckerhoff. NCHRP 08-36 Task 126 Development of Risk Register Spreadsheet Tool; Transportation Research Board, National Academy of Sciences: Washington, DC, USA, 2016.

8. Ministry of Land, Infrastructure and Transport. Task Manual on Design for Safety; Ministry of Land, Infrastructure and Transport: Sejong, Korea, 2017.

9. Korea Expressway Corporation Research Institute. A Development of Risk Management System for Safety Management During Tunnel Construction Stage; Korea Expressway Corporation Research Institute, Hwaseong: Gyeonggi, Korea, 2017.

10. Einstein, H.H.; Indermitte, C.; Sinfield, J.; Descoeudres, F.P.; Dudt, J.-P. Decision aids for tunneling. Transp. Res. Rec. 1999, 1656, 6-13. [CrossRef]

11. Min, S.; Einstein, H.; Lee, J.; Lee, H. Application of the Decision Aids for Tunneling (DAT) to update excavation cost/time information. KSCE J. Civ. Eng. 2005, 9, 335-346. [CrossRef]

12. Hong, E.S.; Lee, I.M.; Shin, H.S.; Nam, S.W.; Kong, J.S. Quantitative risk evaluation based on event tree analysis technique: Application to the design of shield TBM. Tunn. Undergr. Space Technol. 2009, 24, 269-277. [CrossRef]

13. Eskesen, S.D.; Tengborg, P.; Kampmann, J.; Veicherts, T.H. Guidelines for tunnelling risk management: International Tunnelling Association, Working Group No.2. Tunn. Undergr. Space Technol. 2004, 19, 217-237. [CrossRef]

14. Hyun, K.C.; Min, S.; Choi, H.; Park, J.; Lee, I.M. Risk analysis using fault-tree analysis (FTA) and analytic hierarchy process (AHP) applicable to shield TBM tunnels. Tunn. Undergr. Space Technol. 2015, 49, 121-129. [CrossRef]

15. Liu, Y.; Fan, Z.P.; Yuan, Y.; Li, H.Y. A FTA-based method for risk decision-making in emergency response. Comput. Oper. Res. 2014, 42, 49-57. [CrossRef] [PubMed]

16. Zhou, X.Y.; Wang, L.Q.; Qin, J.D.; Chai, J.; Munoz, C.Q.G. Emergency rescue planning under probabilistic linguistic information: An integrated FTA-ANP method. Int. J. Disast. Risk Reduct. 2019, 37, 101170. [CrossRef]

17. Saaty, T. The Analytical Hierarchy Process, Planning, Priority; RWS Publications: Pittshurgh, PA, USA, 1980.

18. Chung, H.; Lee, I.-M.; Jung, J.-H.; Park, J. Bayesian networks-based shield TBM risk management system: Methodology development and application. KSCE J. Civ. Eng. 2019, 23, 452-465. [CrossRef] 